\title{
Spontaneous arterial dissection: phenotype and molecular pathogenesis
}

\author{
Caspar Grond-Ginsbach • Rastislav Pjontek • \\ Suna Su Aksay • Alexander Hyhlik-Dürr • \\ Dittmar Böckler · Marie-Luise Gross-Weissmann
}

\begin{abstract}
Arterial dissection (AD) is defined as the longitudinal splitting up of the arterial wall caused by intramural bleeding. It can occur as a spontaneous event in all large and medium sized arteries. The histological hallmark of $\mathrm{AD}$ is medial degeneration. Histological investigations, gene expression profiling and proteome studies of affected arteries reveal disturbances in many different biological processes including inflammation, proteolytic activity, cell proliferation, apoptosis and smooth muscle cell (SMC) contractile function. Medial degeneration can be caused by various rare dominant Mendelian disorders. Genetic linkage analysis lead to the identification of mutations in different disease-causing genes involved in the biosynthesis of the extracellular matrix (FBN1, COL3A1), in transforming growth factor (TGF) beta signaling (FBN1, TGFBR1, TGFBR2) and in the SMC contractile system (ACTA2, MYH11). Genome wide association studies suggest that the CDKN2A/ CDKN2B locus plays a role in the etiology $\mathrm{AD}$ and other arterial diseases.
\end{abstract}

C. Grond-Ginsbach $(\bowtie) \cdot$ R. Pjontek · S. S. Aksay

Department of Neurology, University of Heidelberg, Heidelberg, Germany

e-mail: Caspar.Grond-Ginsbach@med.uni-heidelberg.de

A. Hyhlik-Dürr · D. Böckler

Department of Vascular Surgery, University of Heidelberg,

Heidelberg, Germany

M.-L. Gross-Weissmann

Department of Pathology, University of Heidelberg,

Heidelberg, Germany
Keywords Arterial dissection - Aortic disease . Medial degeneration - Transforming growth factor (TGF) beta signaling - Smooth muscle cell (SMC) . Matrix metalloproteinase (MMP) - Genetics

\section{Introduction}

Spontaneous arterial dissection (AD) was considered as a very rare disease before modern imaging enabled its diagnosis in a growing number of patients. Pathognomonic signs of AD are (1) an intimal tear/intimal flap, (2) a mural hematoma or (3) a double arterial lumen. Most dissections are diagnosed in the ascending and descending thoracic aorta or in the cervical arteries with estimated annual incidences of 3-6/100,000 [1-4] followed by the intracranial, renal and coronary arteries. Dissections of the abdominal aorta that are not extensions of thoracic aortic dissections are rare [5] and will not be considered in this review. Some authors assume that a considerable number of ADs occur without major clinical signs and may remain undiagnosed even nowadays [6-8].

AD can entail serious complications like sudden heart death, aortic rupture, visceral ischemia, ischemic stroke, subarachnoid hemorrhage and renal failure. As a consequence $\mathrm{AD}$ has been studied over the years in different medical fields such as cardiology, neurology, heart and vascular surgery or pathology. This study tries to overcome the fragmentation of AD research and brings findings from different arteries and different bio-medical fields together. Histopathological and molecular studiesprimarily based on thoracic aortic aneurysms and dissections (TAAD)_give insight to basic pathological processes underlying $\mathrm{AD}$. We focus on the role of 
mutations and associated genetic polymorphisms, since genetics enables the identification of causal factors $[9,10]$. Genetic research revealed that defects in (1) extracellular matrix (ECM) structure, (2) regulation of transforming growth factor (TGF)-beta signaling and (3) smooth muscle cell (SMC) function and proliferation are involved in the pathogenesis of AD. Our study focuses on the pathogenesis of $\mathrm{AD}$, but we discuss aneurysms at several occasions, since both vascular diseases might depend on a similar underlying pathology.

\section{The disease phenotype}

\section{Different forms and stages}

$\mathrm{AD}$ is characterized by a hemorrhage within the arterial wall or by a tear in its intimal layer. The intimal tear may connect the true arterial lumen with a false or second lumen within the arterial wall.

$\mathrm{AD}$ often develops suddenly without warning signs and in absence of traditional vascular risk factors [11]. In contrast to the spontaneous and acute occurrence of $\mathrm{AD}$, the morphology and histology of affected arteries usually reveal the presence of chronic, asymptomatic pathologic alterations associated with non-specific traits like arterial stiffness, dilation, premature arterial occlusion and medial degeneration. Figure 1 interprets the pathological findings as different morphological types and developmental stages of AD. Initial lesions that predispose for a dissection affect the medial layer of the artery and have been described as mediolytic (dissolution of components of the medial layer, Fig. 1a) or as dysplastic (abnormal proliferation of smooth muscle cells, leading to a thickened arterial wall, Fig. 1b). These medial changes might be promoted by inherited and environmental factors, but can also be caused by injury: either as a consequence of endovascular manipulations or due to atherosclerotic ulceration (Fig. 1c). Medial degeneration might result in local aneurysmatic dilatation of the vessel. Impaired blood supply from the adventitial vasa vasorum and chronic adventitial inflammation are considered as further factors that weaken the medial layer (Fig. 1d).

Triggering factors like an abrupt or extreme movement $[12,13]$, excessive physical activity [14-17], minor trauma or a hypertensive crisis are thought to induce an acute bleeding within the defective arterial wall (Fig. 1f). The resulting intramural hematoma can also develop without a communication with the arterial lumen (Fig. 1e). After local iatrogenic injury of the vessel wall a pseudoaneurysm may develop (Fig. 1g).

Different forms of $\mathrm{AD}$ prevail in distinct locations. Acute dissections of the aorta can develop into chronic

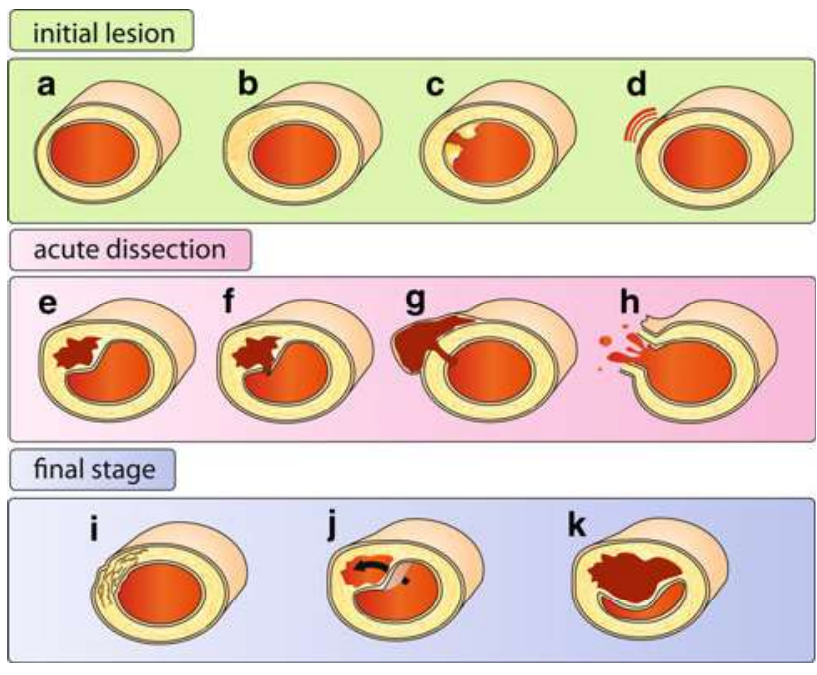

Fig. 1 Forms and stages of arterial dissection. Initial lesion Several types of injury of the arterial wall may predispose to AD. Degenerative alterations may include loss of SMC with fragmentation and depletion of elastic fibers (a) or proliferation of SMCs with irregular and local thickening of medial and intimal layers (b). Mechanical injury due to endovascular operations, atheromatous ulcer (c), as well as peri-adventitial inflammation (d) and small adventitial bleedings [75] are further predisposing factors. Acute AD may present with an intimal tear and intimal flap (f) or as an intramural hematoma without apparent communication with the lumen (e). If $\mathrm{AD}$ causes aneurysmal dilatation of the artery (g), it is often referred to as pseudoaneurysm [2], but others use this notion to describe a hematoma with is located outside the arterial wall, due to a leaking hole in the arterial wall, usually due to an endovascular intervention. Arterial rupture (h) is a most serious complication of AD. Final stage AD may heal spontaneously (i) or develop into chronic forms with a double (false) lumen (j) or a persistent stenosis (k), occlusion or arterial dilatation

forms with a double lumen (Fig. 1j), a rarity for dissections in other arteries. Intramural hematoma without intimal tear (Fig. 1e) is very common in cervical arteries [18, 19], but not in the aorta [20]. The risk of rupture is elevated in aortic and intracranial $\mathrm{AD}$, but not in the extracranial part of the carotid arteries. The different forms of AD probably correlate with local differences in vessel anatomy, vulnerability and blood flow shear forces.

$\mathrm{AD}$ is a dynamic event. The initial and local splitting up of the arterial wall can expand along the artery in downstream as well as in upstream direction. Extracranial dissections of the vertebral arteries can extend into the cranium and develop into intracranial dissections with the risk of subarachnoid or intracerebral hemorrhage. Aortic dissections can expand from the thoracic into the infrarenal segment or into its branches. Dissections may heal spontaneously (Fig. 1i) or develop into a permanent chronic dissection with double lumen with or without chronic expansion (Fig. 1j). Rupture is a serious acute complication of AD (Fig. 1h). 
Common characteristics

\section{Incidence}

Rigorous population based prospective studies about the epidemiology of AD are rare. Since most of the observations were made in hospital based study samples, asymptomatic and fatal cases might be underrepresented. Moreover, dissections have been usually investigated as causes for particular diseases by medical specialists. Reduced attention to symptoms concerning other organ systems might result in further recruitment bias. Epidemiological studies suggested that $\mathrm{AD}$ is rare in all arteries with a yearly incidence in the order of magnitude of $1: 100,000[1,3,7,21,22]$. Most patients are male and develop $\mathrm{AD}$ during midlife. It is unclear, whether the age peak is similar for both sexes or whether the occurrence of $\mathrm{AD}$ in women is more evenly distributed over all ages. The incidences of aortic dissection and cervical AD show seasonal variation and are highest in winter [23, 24].

Given the low incidence of $\mathrm{AD}$, the frequency of bilateral dissections (of the cervical, renal, coronary or intracranial arteries) is remarkably high (Table 1). Most bilateral dissections occur simultaneously or within a short time interval. Interestingly, the coincidence of dissections in different arteries is less frequent. These findings suggest that patients suffer a transient vasculopathy with an increased risk for a specific $\mathrm{AD}$ location. A predisposition for $\mathrm{AD}$ in general, independent of its specific location, seems to be very rare and was demonstrated only in some familial cases [2] and in some patients with connective tissue syndromes, as described below.

\section{Symptoms and complications}

Symptoms and complications of $\mathrm{AD}$ are summarized in Table 2. Pain is the leading symptom of AD in all arteries. It has a sudden onset and is described as unusual, severe, sharp or tearing, unbearable, or "worst ever" by most patients. The location of the pain usually correlates with the site of the dissection. Pain appears typically as an early sign of $\mathrm{AD}$ and is considered as a direct symptom of the arterial injury itself. AD may cause a wide range of complications, dependent on the type of lesion (vessel collapse or rupture) as well as its location. Malperfusion syndromes due to hemodynamic impairment usually develop gradually but without delay, whereas embolism originating from the dissected artery can cause abrupt ischemic symptoms days after the first symptoms of a cervical AD [25]. Myocardial ischemia, pericardial tamponade or cardiac failure and stroke are main complications of dissections of the ascending aorta (Stanford A), whereas patients with dissections of the descending thoracic aorta (Stanford B) present with ischemia of viscera, kidneys or lower limbs [1]. Renal failure is a complication of isolated renal artery dissection [26]. Most patients with cervical AD present with transient ischemic attack (TIA) or thrombo-embolic ischemic stroke [2, 4]. Subarachnoid hemorrhage is a serious complication of intracranial $\operatorname{AD}[22,27]$. All acute ADs, particularly those with increased risk for arterial rupture or ischemic injury of supplied downstream tissues, are emergency cases that require immediate surgery or aggressive medical therapy. However, due to its rarity and the broad range of its complications the immediate diagnosis of $\mathrm{AD}$ was not always possible.

Table 1 Baseline characteristics

\begin{tabular}{llllllll}
\hline Artery & Ascending aorta & Descending aorta & Ren. A. & ICA & VA & Intracran. Aa. & Coron. Aa. \\
\hline Incidence/100,000/year & $3-4$ & $1-2$ & $<1$ & ca. 3 & ca. 1 & ca. 1 & $<1$ \\
Age & 60 & 65 & 50 & 45 & 40 & $<40$ & 40 \\
Male sex (\%) & 65 & 70 & 70 & 60 & 50 & 70 & 25 \\
Bilateral cases (\%) & - & - & $10-15$ & $10-15$ & 15 & $10-30$ & 30 \\
\hline
\end{tabular}

ICA internal carotid artery, ren $A$. renal artery, $V A$ vertebral artery

Table 2 Symptoms and complications

\begin{tabular}{|c|c|c|c|c|c|c|c|}
\hline Artery & Ascending aorta & Descending aorta & Ren. A. & ICA & VA & Intracran. Aa. & Coron. Aa. \\
\hline Symptoms & Pain & Pain & Pain & Pain & Pain & Headache pain & Pain \\
\hline Complications & $\begin{array}{l}\text { Aortic rupture } \\
\text { MI } \\
\text { Neurological complications }\end{array}$ & $\begin{array}{l}\text { Aortic rupture } \\
\text { Organ/leg ischemia }\end{array}$ & HTN & $\begin{array}{l}\text { Horner syndrome } \\
\text { Brain ischemia }\end{array}$ & Brain ischemia & $\begin{array}{l}\text { Brain ischemia } \\
\text { SAH }\end{array}$ & $\begin{array}{l}\text { MI } \\
\text { Acute coronary } \\
\text { syndrome }\end{array}$ \\
\hline
\end{tabular}

$\overline{I C A \text { internal carotid artery, ren. A. renal artery, VA vertebral artery, } M I \text { myocardial infarction, } H T N \text { hypertension, } S A H \text { subarachnoid hemorrhage }}$ 


\section{Risk factors}

Controlled studies of risk factors for AD have rarely been performed. Hypertension seems to be a common risk factor for $\mathrm{AD}$ [8, 26, 28, 29], but patients might also present with hypertension as a reaction on the acute event (Table 3 ). The association between arterial dissection and smoking is less well investigated. More consistent is the finding of mild trauma, mechanical stress and severe physical exercise as risk factors for acute $\mathrm{AD}[12,15,30,31]$. The role of mechanical injury was analyzed in detail for vertebral AD. Chiropractic treatment of the cervical region might be responsible for some reported dissections. However, some of the patients presenting with ischemic stroke after a chiropractic treatment may have suffered from neck pain due to an unrecognized, but already pre-existing AD. In those cases, the chiropractic maneuver might not have caused the dissection event itself, but might have induced its ischemic complication which is thrombo-embolic in most cases $[13,32]$. The association with pregnancy and childbearing [33-36] is not sufficiently explained by the mere physical effort of parturition and the association with coronary or cervical AD seems to be particularly strong during the first weeks post partum. Some case reports suggest that oral contraceptives and hormone replacement therapy increase the risk for coronary AD [37]. A number of patients suffered dissections of different arteries after cocaine consumption [38-42]. Cocaine abuse was found to be a major risk factor for aortic dissections in a series of young patients from San Francisco [43], but in the large International Registry of Acute Aortic Dissection (IRAD) the number of events following cocaine abuse is low [20, 44].

Several studies suggest that infectious diseases, in particular recent upper respiratory infections, increase the risk for carotid AD [45-49]. Imaging techniques using positron emission tomography (PET) to detect ${ }^{18} \mathrm{~F}$-fluorodeoxyglucose (FDG) visualize the uptake of FDG which reflects the presence of metabolically active cells. PET studies revealed also signs of perivascular inflammation in arteries with a spontaneous but not with a traumatic cervical AD [50]. In those patients with spontaneous cervical AD inflammatory signals were also observed along the contralateral non-affected artery, which indicates that FDG uptake along the affected artery is not caused by reactive inflammation after the dissection event. Several PET studies were performed with patients with aortic disease [51-53]. These studies revealed vessel wall inflammation in one-third of the patients with acute aortic syndrome and this patient group seemed to have a high risk for disease progression [54].

\section{Cellular and molecular phenotypes}

\section{Histopathology}

Pathologic alterations are a common finding in biopsies from dissected arteries (Fig. 2). The observed pathologic alterations are (1) chronic and preceding the acute dissection event for a long time, (2) characterized by fragmentation and rarefication of elastic components, (3) involving the medial layer of the arterial wall, (4) focal and (5) not strongly associated with traditional vascular risk factors like hypertension, smoking, obesity, age or diabetes mellitus. Importantly, these findings are not specific for spontaneous $\mathrm{AD}$ but were also observed in arteries with aneurysms and - at a low degree - even in arteries from healthy individuals of high age [55]. The histopathology of affected arteries in patients with $\mathrm{AD}$ is not uniform and a variety of degenerative abnormalities were defined.

The most common histopathological alterations were initially described as "cystic medial necrosis" or "mucoid (or myxoid) medial degeneration". They are defined as a non-inflammatory process in the medial layer of arterial walls with focal loss of smooth muscle cells (SMC), fibrosis, accumulation of basophilic ground substance and fragmentation of elastic laminae [56].

Table 3 Risk factors

\begin{tabular}{|c|c|c|c|c|c|c|c|}
\hline Artery & Ascending aorta & descending aorta & Ren. A. & ICA & VA & Intracran. Aa. & Coron. Aa. \\
\hline Hypertension & + & ++ & + & + & + & + & + \\
\hline Smoking & + & + & - & + & + & + & - \\
\hline Mild trauma & + & + & + & + & + & + & + \\
\hline Severe exercise & + & + & + & + & + & + & + \\
\hline Pregnancy/puerperium & + & + & + & + & + & $(+)$ & ++ \\
\hline Oral contraceptive & $(+)$ & $(+)$ & $(+)$ & $(+)$ & $(+)$ & $(+)$ & + \\
\hline Cocaine & + & + & $(+)$ & $(+)$ & $(+)$ & $(+)$ & + \\
\hline
\end{tabular}

$I C A$ internal carotid artery, ren. $A$. renal artery, $V A$ vertebral artery, $+=$ significant association with risk factor, $(+)=$ association with risk factor is weak or not documented 
Fig. 2 Histology of aortic medial degeneration. Normal aorta (left side) and aorta with medial degeneration stained with Hematoxylin and eosin (right side). Thin arrows point to elastic fibers, arrowheads point to SMC nuclei. Note areas with pronounced focal fibrosis, loss of SMC, loss of elastic fibers and accumulation of eosinophilic ground substance in aorta with medial degeneration (encircled areas)
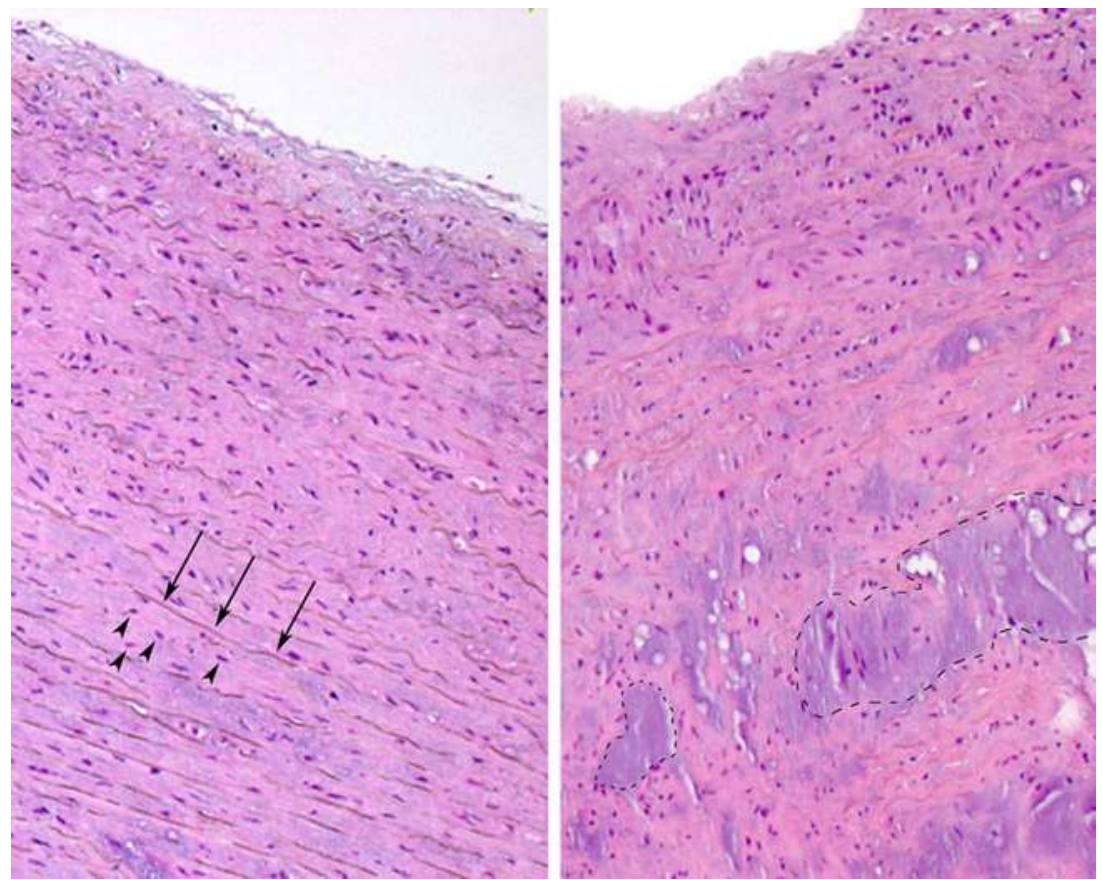

Fibromuscular dysplasia is another disease of the vessel wall that was associated with $\mathrm{AD}$, mainly in the renal and the cervical arteries. It is a non-inflammatory, non-atherosclerotic disease that has been reported in almost every arterial bed and primarily affects women aged $15-50$ years $[57,58]$.

Intimal thickening resulting in stenosis is another vascular pathology that is associated with aortic dissection as well as with atherosclerosis. It was recently described in more detail in patients with familial TAAD and mutations in the alpha-actin-2 (ACTA2) gene that codes for SMC specific actin (see below). It is unclear, whether these various pathologies are to be considered as different diseases or as variable signs of a same underlying disease. More important, the connections between these different pathologies and atherosclerosis are complex and to a large extend unknown.

Atherosclerosis is a risk factor for aortic disease, in particular for the abdominal part, and might thus be involved in the associated vascular morphology. The risk profiles of cervical $\mathrm{AD}$ or coronary $\mathrm{AD}$ or renal $\mathrm{AD}$ do not indicate a significant association between these diseases and atherosclerosis. Inflammation, however, seems to accompany both atherosclerosis and the various degenerative diseases of the vessel wall that predispose to AD.

Histopathological studies of the aorta identified signs of SMC apoptosis within areas of medial degeneration in the absence of inflammation [59]. Other studies claim that T-Lymphocytes (CD3+) and macrophages (CD68+) accumulate upon medial degeneration and that the focal loss of SMCs is attributable to the local expression of death-promoting mediators by these immune infiltrates
[60]. Eosinophilic infiltrations were found in the adventitial layer of dissected coronary arteries [61] which suggested that isolated eosinophilic arteritis can entail coronary AD. The contradictory results are difficult to explain [62]. Anatomical and physiological differences along the arterial tree play probably a role. Not all studies perceived that the nature of the SMCs varies along the arterial tree: neural crest derived SMCs prevail in the ascending aorta and its proximal branches, whereas other SMCs are of mesodermal origin. This is of importance, because the ontogenetic origin of the SMC is associated with opposite responses to TGF-beta stimulation [56].

\section{Proteases involved in matrix degradation}

Proteases, including matrix metalloproteinases (MMPs), cathepsins, chymase, tryptase, neutrophil derived serine elastase, tissue type plasminogen activator (tPA), urokinase type plasminogen activator ( $\mathrm{UPA}$ ) and plasmin are found in excess in aortic aneurysms and dissections. The main sources of proteases in the arterial wall are macrophages, neutrophils, fibroblasts and vascular smooth muscle cells. Furthermore, the mural thrombus, frequently observed by atherosclerotic aneurysms and in the false lumen of chronic dissections, tends to trap leucocytes and absorb plasma components, thus might act as a source of proteases in arterial diseases. [63] Numerous proteases have been implicated to cause ECM-destruction in aortic diseases and might account for the expansion of areas with medial degeneration, most prominent among which are the members of the matrix metalloproteinase (MMP) family. 
MMPs are a family of structurally-related, zinc-dependent endopeptidases. The members of the MMP family are collagenases, gelatinases, stromelysins, matrilysins, membrane-type MMPs. Collectively they are capable of degrading all kinds of extracellular matrix proteins. MMPs are synthesized as inactive zymogens with a pro-peptide domain that must be removed before the enzyme becomes active. Under physiological conditions, the activity of MMPs is regulated at the level of transcription, activation of the precursor zymogens and interaction with specific ECM components [64]. With their proteolytic activity MMPs play an important role in vascular remodeling and cellular migration. Gelatinases-MMP2 and MMP9-are the most intensively studied MMPs, which are involved in the development of aortic diseases. They share substrate affinity to short collagens, degradation products of interstitial collagen and elastin. TIMPs - tissue inhibitors of MMPs - have inhibitory effects on the proteolytic activity of MMPs. The role of extracellular matrix proteolytic systems in $\mathrm{AD}[64,65,68]$ and aneurysm formation and progression $[56,66]$ was extensively studied. The imbalance between the activity of MMPs and their tissue inhibitors (TIMPs), low TIMP2/MMP2 and low TIMP2/ MMP9 ratios respectively, might play an important role in ECM destruction and aortic dissections [67]. MMP3 and MMP7 have high affinities for sulphated residues and are able to degrade numerous adhesive glycoproteins. High concentrations of these MMPs were recently found in the proteoglycan-rich mucoid depositions within the medial degeneration areas of ascending aortic aneurysms and dissections [68]. It is also suggested that MMPs have direct or indirect effects on ion channels in the endothelium and SMCs and take part on the regulation of vascular contraction or relaxation. MMPs can also act as regulatory molecules controlling cellular interactions, both by functioning in enzyme cascades and by processing matrix proteins and adhesion molecules. MMPs and its inhibitors will also be discussed in relation with TGF-beta signaling.

\section{Whole genome expression studies}

Gene expression profiling studies were performed to characterize the vascular phenotype of dissected arteries in molecular terms. Gene expression profiling involves quantifying mRNA levels by probing the total mRNA (= transcriptome) with specific sequences that are fixed on a slide. Thousands of transcripts in a biological sample can thus be analyzed simultaneously. Gene expression profiles of arterial biopsies from patients were compared with nonaffected arterial segments or with material from healthy control persons. Differences in signal intensity does not necessarily indicate differential gene expression but might reflect any difference between the compared tissue biopsies including inequalities in cellular composition or imperfect matching of the study samples. Various array systems with different numbers of targeted transcripts are currently used and evaluated with a growing number of statistical tools.

The expression profile of acute dissections of the ascending aorta [69, 70] showed increased signals for interleukin 8 (IL8), interleukin 6 (IL6) and some further genes involved in chronic inflammation. The signal intensities of transcripts which play a role in SMC contraction like myosin regulatory light chain 2 and actin alpha 2 were lower in dissected aortic biopsies than in control material. Hierarchical clustering of the expression profiles revealed perfect separation of control tissue and patients. Most interestingly, tissue samples taken from dissected aortic wall and from macroscopic intact aortic wall from the same patient showed highly similar expression profiles. In all cases, samples taken from the same aorta (dissected and unaffected parts) were more similar to each other than to any of the other samples. The increased level of IL6 and IL8 transcripts, together with significant up-regulation of transcripts of CD25 (found on activated B-cells and T-cells), CD53 (leukocyte surface antigen) and of MNDA (myeloid cell nuclear differentiation antigen) indicated that medial degeneration was accompanied by immune cell infiltration. Increased expression of IL6 and IL8 was also found in whole genome expression profiling studies of abdominal aortic aneurysms (AAAs) [71, 72]. A recent gene expression profiling study of the intracranial aneurysm wall also supported the involvement of the inflammatory response pathway, but the expression of IL6 and IL8 was reduced in the aneurysm wall [73, 74]. However, in this study the material of the aneurysm wall was not compared with tissue from healthy control individuals but with the superficial temporal artery from the same patient. The choice this control material explain some of the discrepancies between this study and earlier gene expression profiling studies on aortic disease. The superficial temporal artery from patients with cervical AD showed significant signs of an inflammatory systemic vasculopathy with adventitial infiltrates [75]. In this latter study the authors even assumed that the pathologic changes in the temporal and cervical arteries are similar.

In summary, gene expression profiling as well as other studies show that inflammation plays a role in medial degeneration, but there some inconsistencies between the different findings that might be partially explained by the local diversity of the SMC population and by focal differences between analyzed biopsies [56, 76].

Several other functional pathways are involved in the molecular phenotype of AD. The most impacted pathways in medial degeneration of the intracranial aneurysm wall were focal adhesion, extracellular matrix receptor interaction, cell communication, inflammatory response and 
apoptosis [73]. In acute Stanford A dissection genes involved in inflammation, extracellular matrix proteolysis, proliferation, hemostasis, SMC proteins and focal adhesion were differentially expressed [69, 70]. Similar alterations were found in other arterial diseases. Thoracic aortic aneurysms were found strongly associated with differential regulation of genes involved in cell proliferation and apoptosis, whereas genes involved in atherosclerosis and chronic inflammation were increasingly expressed in AAAs. The most common alteration in both thoracic and abdominal aortic aneurysms was the marked increase in expression of MMP9 [72]. MMP9 is thought to contribute to elastin degradation in aneurysmal disease as it exhibits enzymatic activity against elastic fibers and other extracellular matrix proteins and it is produced by medial SMCs and aneurysm-infiltrating macrophages. Transcripts of SMC-specific genes were generally down-regulated upon medial degeneration $[69,73]$. This might indicate loss of SMCs, but the low expression of SMC-specific actin, myosin or other genes involved in contractile function might also indicate the activation of SMCs upon vessel wall injury and their transition from the contractile into a proliferating, synthetic or apoptotic stage [77].

\section{Predisposing genetic variants}

Genetic syndromes with an increased risk for arterial dissections

Three well known inherited connective tissue disorders are associated with AD: Marfan syndrome, the vascular type of Ehlers Danlos syndrome (vEDS) and Loeys-Dietz syndrome. Turner Syndrome is a fourth condition with increased risk for arterial dissections.

\section{Marfan syndrome}

Marfan syndrome is an autosomal dominant inherited disorder with a prevalence of about 1:10,000. Typical signs of Marfan syndrome are chest deformities and disproportionate long limbs caused by long bone overgrowth, dislocation of the ocular lenses, dural ectasia and aortic dilatation and dissection, predominantly at the aortic root. Heterozygous mutations in the fibrillin-1 (FBN1) gene were identified as the cause of Marfan syndrome [78, 79]. Since mutation search in FBN1 is expensive and time consuming, the diagnosis of Marfan syndrome is not always confirmed by molecular techniques. Moreover, the mutation detection rate in FBN1 is incomplete and Marfanlike phenotypes can be caused by mutations in other candidate genes like TGFBR2 (transforming growth factor, beta receptor 2$)$. In a large $(n>1,000)$ series of patients with confirmed molecular diagnosis $15 \%$ of the patients had a dissection of the ascending aorta in, $4 \%$ of the descending aorta and $3 \%$ had dissection of the abdominal aorta. No dissections in other arteries were reported [80]. Medial degeneration is a typical finding in aortic biopsies [81].

\section{Ehlers Danlos syndrome}

Ehlers Danlos syndrome (EDS) is a clinically and genetically heterogeneous connective tissue disorder, caused by genetic defects in collagen biosynthesis. Arterial involvement is mainly observed in the vascular type of EDS, formerly designed as EDS type IV [82]. Additional subtypes of EDS that predispose to AD were recently defined as the "vascular-like EDS subtype" and the "EDS/OI (Osteogenesis imperfecta) overlap syndrome" [79]. Vascular EDS is a rare autosomal dominant disorder (estimated prevalence below $1: 100,000)$ caused by mutations in the gene that codes for type III procollagen (COL3A1). The clinical phenotype seems mild, but vascular EDS is a life threatening disorder due to the high risk of organ rupture (intestine, uterus, or aorta). About $40 \%$ of patients presents with vascular events by 40 years of age, typically aortic rupture and in a minority of cases carotid artery dissections. Arterial complications are slightly more frequent among male patients.

\section{Loeys-Dietz syndrome}

Loeys-Dietz syndrome, a rare autosomal dominant genetic disorder with clinical similarities to vascular EDS, was recently identified in patients with mutations in the transforming growth factor beta receptors 1 and 2 (TGFBR 1 and TGFBR2) [83]. Two subtypes of the disorder are recognized. Patients with Loeys-Dietz syndrome type 1 present with aneurysms and dissections of the thoracic aorta as well as in other arteries. Additional symptoms of this syndrome are hypertelorism, cleft palate/bifid uvula, craniosynostosis, mental retardation, patent ductus arteriosus and arterial tortuosity. Patients with Loeys-Dietz syndrome type 2 resemble patients with vascular EDS. They do not show craniofacial abnormalities, but develop arterial aneurysms and dissections together with joint laxity, easy bruising, translucent skin and atrophic scars. Histopathological findings in the aorta show medial degeneration with pronounced fibrosis and elastic fiber fragmentation [84].

\section{Turner syndrome}

Turner syndrome is a developmental disorder caused by partial or complete monosomy of the $\mathrm{X}$ chromosome. The prevalence of Turner syndrome is about 1 in 2,500 live 
births. Turner syndrome is a common cause of aortic dissection in young women $[85,86]$, but the pathogenesis of aortic dissection is unclear. The risk for fatal aortic events was particularly high in pregnant Turner women (via egg donation). In patients with Turner syndrome, dissections are predominantly located in the ascending aorta. Medial degeneration was observed in biopsies from the majority of Turner patients with aortic dissection [87, 88].

\section{Mutations in patients with familial AD}

Familial clustering is reported for patients with $\mathrm{AD}$ but without additional signs of a known inherited disorder. Familial clustering of thoracic aortic aneurysms and dissections was found in 15-20\% of all cases [89-91] and is also evident for intracranial aneurysms and subarachnoid hemorrhage [92]. On the contrary, familial cervical AD is very rare [93]. These observations suggest a different impact of genetic factors in the pathogenesis of these diseases.

Recent developments in the elucidation of familial ADs are mainly based on the study of familial aortic dissection. Linkage and mutation analysis in patients with familial thoracic aortic aneurysms and dissections (TAAD) identified mutations in FBN1, TGFBR1, TGFBR2 in patients without other symptoms of the Marfan, Loeys Dietz or Ehlers Danlos syndromes. The co-segregation of the identified familial mutations with the disease phenotype strongly suggests a causative role for the mutations in the pathogenesis of $\mathrm{AD}$. Disease-causing mutations were also identified in ACTA2 (encoding smooth muscle alpha-actin) and MYH1 1 (encoding smooth muscle beta-myosin heavy chain). In most families the mutations in FBN1, TGFBR1, TGFBR2, ACTA2 and MYH11 affect the aorta, but some relatives with TGFBR1 and ACTA2 mutations suffered dissections in other arteries (Table 4). The penetrance of ACTA2 mutations is only about $50 \%$, i.e. only half of the family members carry a mutation present with arterial disease. As a consequence ACTA2 mutations might also be detected in sporadic patients. Mutations in several other genes (COL3A1, COL1A1, COL5A2) were found in some rare sporadic or familial cases with arterial disease [93-95], but their importance in the pathogenesis of $\mathrm{AD}$ without other signs of a known connective tissue disorder is less well established. The spectrum of mutations identified in familial TAAD points to three biological systems involved in the pathogenesis of $\mathrm{AD}$ : 1 connective tissue structure, 2 TGF-beta signaling and $3 \mathrm{SMC}$ function and proliferation.

\section{Connective tissue defects}

The association of $\mathrm{AD}$ with known inherited connective tissue syndromes and the observation of morphologic alterations in the dermal connective tissue of patients with cervical AD [96, 97] and intracranial aneurysms [98] supported the hypothesis of a generalized structural connective tissue defect predisposing for $\mathrm{AD}[2,99]$ even in sporadic patients without evident signs of a connective tissue disorder [11]. Mutations in COL3A1, COL5A2, COL1A1 and ACTA2 were found in sporadic patients with cervical $\mathrm{AD}$ without further signs of a connective tissue syndrome [100, 141]. Arterial complications as major or isolated sign were also found in part of the large series of patients with COL3A1 mutations [82]. Carriers of FBN1 mutations may present with isolated ascending aortic dilatation [101].

Based on a static concept it was initially assumed that the reduced or altered biosynthesis of mutated components of the ECM lead to structural weakness of the vessel wall which explained the increased risk for AD. However, inflammatory and degenerative processes accompany the structural defects of the vascular ECM and are crucial for the vascular phenotype.

Several studies suggested a crucial role for fibrillin, elastin, and collagen fragments in SMC signaling [102]. Elastin is one of the dominant ECM proteins in the arterial wall. It is deposited and cross-lined in the elastic fibers along the fibrillin containing microfibrils. Collagen might play an important role in matrix signaling, too. Collagens are recognized by two major classes of receptors: the beta1 family of integrins $(\alpha 1 \beta 1, \alpha 2 \beta 1, \alpha 10 \beta 1, \alpha 10 \beta 1)$ and DDR1

Table 4 Genes involved in the pathogenesis of $\mathrm{AD}$

\begin{tabular}{lllll}
\hline Gene & Locus & Involved arterial component & Syndrome & Arterial phenotype \\
\hline COL3A1 [82] & $2 \mathrm{q} 31$ & Collagen biosynthesis & Vascular EDS & Aortic rupture cervical AD \\
FBN1 [78] & $15 \mathrm{q} 21$ & Elastic fiber biosynthesis/TGF-beta signaling & MS & TAAD \\
TGFBR1 [83] & $9 \mathrm{q} 22$ & TGF-beta signaling & LDS & TAAD/AD in other locations \\
TGFBR2 [83] & $3 \mathrm{p} 22$ & TGF-beta signaling & LDS/MS & TAAD \\
ACTA2 [118] & $10 \mathrm{q} 23$ & SMC function & No & TAAD/PAOD AD in other locations \\
MYH11 [119] & $16 \mathrm{p} 13$ & SMC function & No & TAAD/PDA \\
CDKN2A/B [127] & $9 \mathrm{p} 21$ & SMC senescence & No & IA, Aortic dissection \\
\hline
\end{tabular}

EDS Ehlers Danlos syndrome, IA intracranial aneurysm, LDS Loeys-Dietz syndrome, MS Marfan syndrome, TAAD thoracic aortic aneurysms and dissections, $P A O D$ premature arterial occlusive disease, $P D A$ patent ductus arteriosus 
and DDR2, two members of the discoidin-domain receptor family. Both of these receptor groups are produced by SMCs and are thought to mediate cellular migration, adhesion and proliferation. However, mice lacking some of these receptors failed to reveal significant vascular defects. Therefore, the contribution of collagen signaling to vascular diseases remains unclear at present [102].

A pathogenic frameshift mutation in the filamin A encoding FLNA gene was found in a patient who died of a subarachnoid hemorrhage [103]. Filamin A is the nonmuscle isoform of filamin. It has an important function in the formation of intercellular junctions and the anchoring of the cell to the ECM. FLNA knockout mice show cardiac and vascular developmental abnormalities [104]. Proteomic analysis in aortic media of patients with Marfan syndrome revealed upregulation of the C-terminal fragment of filamin $\mathrm{A}$ in aortic aneurysms from patients with Marfan syndrome [105] and hypertensive rats [106].

\section{Mutations affecting TGF-beta signaling}

The discovery that mutations in the TGFBR2 gene cause Marfan syndrome type 2 as well as the finding of mutations in TGFBR1 and TGFBR2 in patients with Loeys-Dietz syndrome [78] or in families with TAAD and dissections in other arteries [107] revealed the prominent role of TGFbeta signaling in the pathogenesis of arterial disease. TGFbeta signaling is regulated at multiple levels in a highly complex manner. TGF-beta signaling appears to be decisive for the vascular phenotype of classic Marfan syndrome with mutations in FBN1. In mouse models of Marfan syndrome fibrillin deficiency leads to elevated TGF-beta levels. TGF-beta remains inactive as long as it is captured by latent TGF-beta binding protein (LTBP). Increased amounts of fibrillin fragments which show structural homology with LTBP lead to release and proteolytic activation of TGF-beta [108, 109] (Fig. 3). Interestingly, the

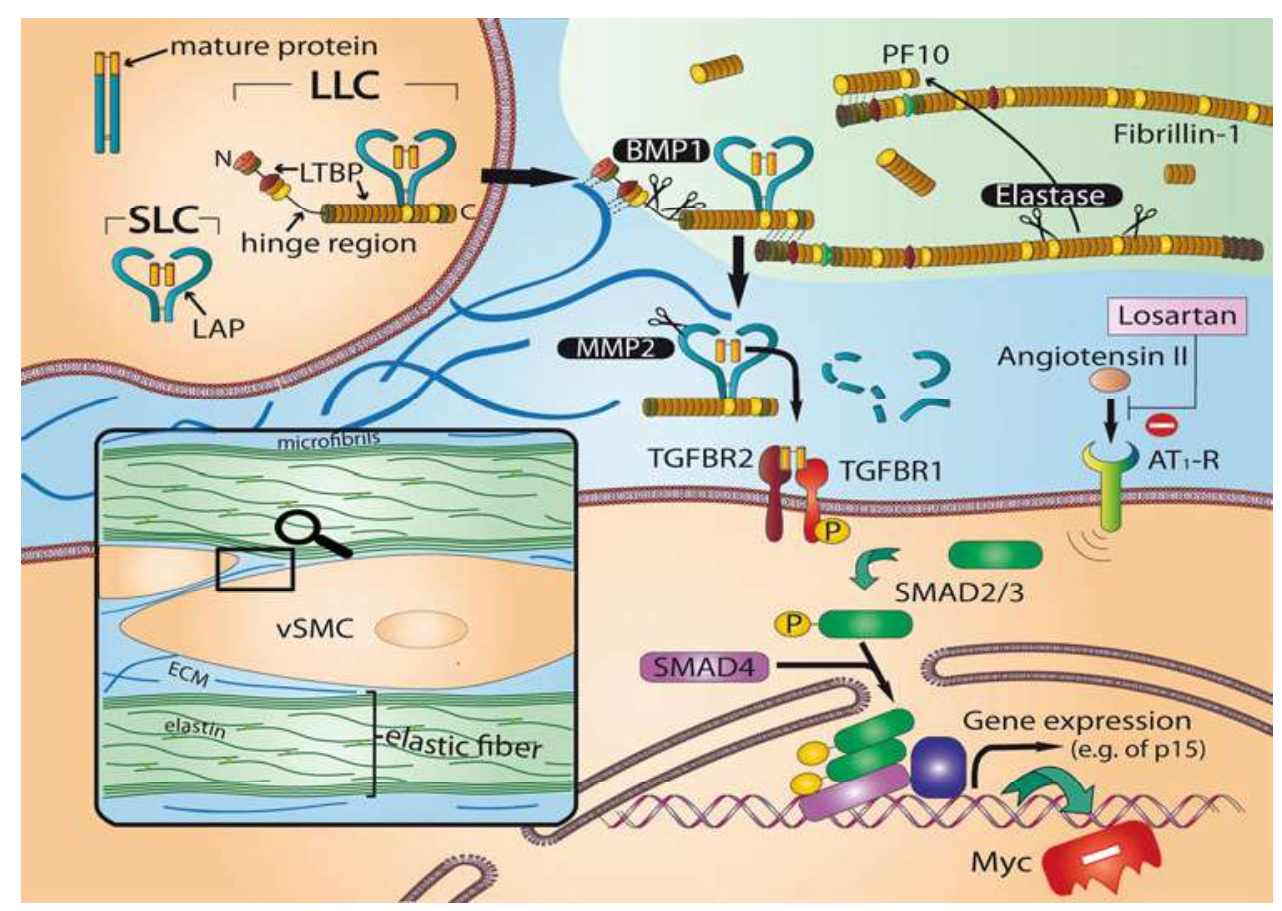

Fig. 3 TGF-beta signaling in the arterial wall. In most cells including SMCs TGF-beta binds to TGFBR2 (type II receptor) and ALK5 (type I receptor, also known as TGFBR1). The inactivation of TGF-beta by latent TGF-beta binding protein (LTBP) is an important mechanism regulating TGF-beta activity within the extracellular compartment and plays a prominent role in the vascular pathology of Marfan and Loeys-Dietz syndromes. The C-terminal domain of LTBP interacts with the N-terminal domain of Fibrillin-1, the major component of elastin-associated microfibrils [152, 153]. Elastase and other proteolytic enzymes release fibrillin fragments by disintegration of microfibrils. Subsequently internal fibrillin fragments bind with high affinity to the N-terminal region of fibrillin-1, the former binding site of LTBP which releases TGF-beta. TGF-beta induces a large set of cytostatic gene responses. TGF-beta stimulates among others $\mathrm{p} 15^{\mathrm{INK} 4 \mathrm{~b}}$ (p15) both by direct Smad-mediated transactivation and by the simultaneous downregulation of the Myc transcription factor, which leads to a rapid cellular depletion of Myc and to relief of p15 transcriptional repression $[154,155]$. AT1-R, Angiotensin-II type I receptor; $\mathrm{BMP}$, bone morphogenetic protein; $\mathrm{LCC}$, large latent complexes, consisting of SCL complexed with latent TGF $\beta$ binding protein (LTPB); PF-10, recombinant human fibrillin-1 fragment encoded by exons 41-52 of the FBN1 gene, interacting strongly and specifically with the N-terminal region of fibrillin-1; SLC (small latent complex) consisting of mature $\mathrm{TGF} \beta$ and latency associated peptide (LAP); SMAD, signal transducer and transcriptional modulator that mediate multiple signaling pathways; vSMC, vascular smooth muscle cell 
aorta of Marfan mice was normal at birth but developed medial degeneration during early life, which was accompanied by inflammatory infiltration. Fibrillin fragments appear to be potent attractants for macrophage chemotaxis in in vitro experiments $[110,111]$.

It is well established that Marfan syndrome and LoeysDietz syndrome are associated with increased TGF-beta signaling, but the relationship between aberrant TGF-beta signaling and the histopathological changes in the arterial wall remain to be elucidated. TGF-beta stimulates the synthesis of procollagens and fibronectin and thus leads to ECM deposition and fibrosis. Accordingly, accumulation of collagen is considered to be an indirect marker of increased TGF-beta signaling. Indeed mice with fibrillin deficiencies show thickening of the aortic media with accumulation of ECM and fragmentation of elastic fibers. MMP2 and MMP9 were up-regulated in Marfan syndrome during the progression of thoracic aortic aneurysms [112] and it is suggested that these MMPs are at least in part responsible for the extensive degeneration of elastic fibres, the endothelium dysfunction and the reduction of smooth muscle contractility. Doxycycline-a tetracycline antibiotic-is a nonspecific inhibitor of MMPs, acting by binding to the zinc-calcium at their catalytic sites. In a mousemodel of Marfan syndrome doxycycline was effective in preventing thoracic aortic aneurysms by preserving elastic fibre integrity, normalizing vasomotor function and suppressing TGF- $\beta$ activation, with mechanisms which are at least in part attributable to its inhibitory effects on MMP2 and MMP9 [113]. Since TGF-beta can stimulate the expression of several MMPs the production of fibrillin fragments may increase due to fibrillin cleavage. This increase leads to a vicious circle because more fibrillin fragments enhance the TGF-beta activation [114].

Antihypertensive treatment may effectively prevent the development of the progression of aneurysmal growth. Genetic studies of the TGF-beta and angiotensin-II type 1 (AT1) receptor pathways revealed that this preventive effect might be partially independent of the blood pressure lowering. A short introduction of this work intends to illustrate the value of genetic research as a tool to unravel complex biological systems. Perfusion with the hypertensive agent angiotensin-II (Ang-II) in mice induced the following vascular alterations: (1) sustained blood pressure elevations; (2) increase in the thickness of the aortic media through mechanisms including smooth muscle hyperplasia, smooth muscle proliferation, and accumulation of ECM proteins; (3) signs of inflammation, including oxidative damage to the vascular tissue, infiltration of monocytes/ macrophages, and activation of MMPs. Not surprisingly, Ang-II treatment induced aortic dissections 6 out of 26 wild-type mice. Animals deficient for NOX1 (NADPH oxidase, a crucial component of the response to Ang-II) had lower blood pressure elevation and only one of 25 developed AD [115]. However, blood pressure elevation by norepinephrine did not lead to aortic dissection in wild type mice, suggesting that hypertension is not sufficient to cause aortic dissection. In fact, Ang-II induces-independent from blood pressure elevations-a multitude of other alterations in the arterial wall, amongst them an altered protease/inhibitor balance. NOX1 was shown to suppress the activity of TIMP1 and it was suggested that NOX1 attenuates the Ang-II-induced TIMP1 gene expression. The effect of losartan might be similarly complex. Losartan, an AT1 1 receptor antagonist, is a widely used medication to decrease blood pressure. A careful comparison of two antihypertensive drugs, losartan and propranolol, in FBN1deficient mice revealed that the beta blocker propranolol may diminish the aortic root growth but cannot prevent progressive deterioration of the aortic wall. However, losartan maintained the aortic wall structure in Fibrillin-1deficient mice and fully prevented aortic root dilatation [116]. The beneficial effect of Losartan is in part independent of its anti-hypertensive effects, like antagonizing TGF-beta. A clinical trial is currently being performed to evaluate the effects of losartan on the progression of aortic root growth rate [117].

\section{Vascular smooth muscle cells}

The finding of disease-causing mutations in ACTA2 and MYH11 in large families with TAAD suggests that dysfunction of SMCs results in medial degeneration leading to $\mathrm{AD}$. The major function of vascular SMCs is to contract in response to the stretch resulting from the blood flow pulses. This contraction is dependent on the interaction between thin filaments, composed of SMC-specific alpha-actin (encoded by ACTA2) and thick filaments, composed of SMC-specific beta myosin (encoded by MYH11). The identification of mutations in specific contractile components of SMCs suggested a causal relation between SMC contractile function and degenerative arterial diseases. Increased amounts of SMCs were found in the medial arterial layer of patients with heterozygous ACTA2 mutations. Cell-proliferation essays of cultured SMCs demonstrated that these arterial cells from patients with ACTA2 mutations proliferated more rapidly than control cells. The increased cell-proliferation correlates with a thickening of the medial arterial layer, leading to stenosis. Premature vascular occlusive disease was diagnosed in about one-third of the carriers of ACTA2 mutations, with ischemic stroke as a possible complication [118]. Moreover, occlusion of vasa vasorum might entail focal arterial ischemic injury and predispose to medial degeneration or to increased arterial vulnerability for atherosclerotic or other lesions. 
Mutations in MYH11 were found in a few families with familial TAAD, associated with patent ductus arteriosus. Patients with MYH11 mutations show a distinctive occlusive arterial pathology [119]. Histological inspection of aortic biopsies revealed specific alterations with areas of focal medial degeneration, increased proteoglycans and loss of elastic fibers and SMCs, as well as areas with SMCs proliferation in a disorganized pattern, resembling the phenotype of fibromuscular dysplasia.

During the formation of aneurysms and dissections of the thoracic aorta the transition of SMCs from the contractile to the synthetic type is accompanied by elevated concentrations of matrix metalloproteinases [120, 121]. It is conceivable that increased MMP concentrations enable SMC migration. Genetic deficiency of MMP2 and MMP9 decreases the in vitro migration ability of SMCs significantly. SMCs express constitutively MMP2 but other MMPs including MMP9 only after stimulation by cytokines. MMP9 is secreted primarily by inflammatory cells, including neutrophils and macrophages. MMP2 and MMP9 can enhance the contractile function of vascular SMCs by inhibiting the $\mathrm{Ca}^{2+}$ entry into the cells from the extracellular space [122]. Interestingly, circulating smooth muscle myosin and circulating MMP9 were also analyzed as possible plasma markers for the diagnosis of aortic dissection and aneurysm [123, 124].

\section{Genetic association studies}

Genetic association studies are case-control studies (or cohort studies) that analyze the prevalence of common genetic variants, usually single nucleotide polymorphismsSNPs, in diseases. Most genetic association studies analyzed the genetic variation in a single candidate gene, but recent technical developments currently permit the simultaneous analysis of hundred thousands of SNPs. Such genome wide association studies (GWAS) require a rigorous design and a careful statistical evaluation $[125,126]$.

A genetic variant on chromosome 9p21.3 was found to be involved in different vascular diseases, including coronary artery disease, abdominal aortic aneurysms, intracranial aneurysms [127, 128] and arterial stiffness [129]. Interestingly, the identified locus harbors the CDKN2A (cyclin dependent kinase inhibitor $2 \mathrm{~A}$ ) and $\mathrm{CDKN} 2 \mathrm{~B}$ genes that code for the senescence markers p16 and p15. Both genes are known to play an important role in cell cycle regulation and belong to a family of genes that have been implicated in the pathogenesis of atherosclerosis through their role in TGF-beta-induced growth inhibition. The most strongly associated SNPs in the 9p21.3 locus lie close to the CDKN2B gene [130]. Recent data indicated that the genetic variation in the $\mathrm{CDKN} 2 \mathrm{~B} / \mathrm{CDKN} 2 \mathrm{~B}$ locus was associated with transcription activity of $\mathrm{CDKN} 2 \mathrm{~B}$ but not of neighboring genes including CDKN2A, MTAP (encoding methylthioadenosine phosphorylase), or ANRIL (a noncoding antisense RNA in the INK4 locus) [131]. Therefore, both $\mathrm{p} 15$ and $\mathrm{p} 16$ are interesting candidates with a possible role in dissection and aneurysm formation. Suppression of the cyclin dependent kinase inhibitor and tumor suppressor p16 resulted in an enhanced SMC proliferation underlying intimal hyperplasia in a carotid arterial injury mouse model [132]. Elevated blood pressure markedly induced p16 expression in rat kidneys and hearts as well as in human kidneys [133]. The tumor suppressor $\mathrm{p} 15$, the gene product of CDKN2B, is a potential effector of TGF-beta-induced cell cycle arrest [134]. It is interesting that some of the involved candidate genes were originally identified in tumor biology.

The TAAD phenotype was analyzed in several candidate gene association studies. TAAD was associated with genetic variants in MMP9 [135] and VKORC1 (encoding the vitamin K epoxide reductase complex, subunit 1) [136], but these results require validation in independent populations. Several candidate gene studies of patients with AAA were recently performed [137-139], but confirmation of the results is warranted. GWAS with large series of patients with TAAD or AAA were not yet published. Genetic association studies of cervical AD revealed that carriers of the T-allele of the MTHFR gene might have an increased risk, but the evidence is weak and the finding needs confirmation in a large and independent population [140]. No other genetic variants were found to be associated with cervical $\mathrm{AD}[141,142]$. The results of a large multicenter GWAS of cervical $\mathrm{AD}$ are to be expected in the near future [143].

\section{Concluding remarks}

The notion of $\mathrm{AD}$ refers to various arterial pathologies including mural hematoma with and without intimal tear, double lumen or pseudo-aneurysm in different arteries. All $\mathrm{AD}$ phenotypes have several risk factors in common and are associated with medial degeneration. The association with genetic syndromes like Marfan syndrome, LoeysDietz syndrome or Ehlers-Danlos syndrome and the finding of electron microscopic alterations in skin biopsies from patients with cervical AD and intracranial aneurysms [99] indicate that $\mathrm{AD}$ may be a symptom of a systemic disease.

However, patients rarely show multiple $\mathrm{AD}$ in different arteries [144-147], whereas the occurrence of bilateral dissections in the carotid, vertebral, renal or coronary arteries is frequent. Moreover, patients with genetic syndromes and familial forms of AD typically suffer dissections in specific arterial segments (ascending aorta in patients with Marfan syndrome, carotid AD in patients with 
vascular EDS). Therefore, we can conclude that some risk factors are specific for a particular arterial segment: genetic as well as environmental risk factors indicate differences between aortic regions and within the cervical arteries.

In this review we brought all forms and stages of $\mathrm{AD}$ together and searched for general and specific pathogenetic factors. Notwithstanding the striking similarities in epidemiology, risk profile and histopathology of most ADs important differences may be masked by not sufficiently differentiated terminology. For instance, the very notion of $\mathrm{AD}$ does not have the exact same meaning when applied to the aorta or to the cervical arteries. Cervical AD is usually characterized by a mural hematoma without intimal tear, whereas such mural hematoma without open communication with the arterial lumen is not common in the aorta. This intimal tear allows free access of thrombolytic agents into the false lumen of the dissected aorta. This may explain why thrombolysis is considered to be safe in patients with cervical $\mathrm{AD}$ and stroke, but potential harmful in patients with aortic dissection [148]. Moreover, the hematoma of a cervical AD is usually older at diagnosis, whereas the arterial hemorrhage in patients with acute aortic dissection is fresh. Other notions with ambivalent sense are pseudo-aneurysm [149, 150]) and dissecting aneurysm [151].

Imaging studies of dissected arteries reveal a variety of vascular abnormalities such as fibromuscular dysplasia, arterial tortuosity, aneurysmal dilatation and arterial stiffness. These different vascular abnormalities are all associated with medial degeneration. The complex molecular signature of medial degeneration has been characterized by independent techniques. Medial degeneration can be accompanied by inflammation, cell proliferation or apoptosis, senescence and increased proteolytic activity. Metalloproteinases and their inhibitors play a prominent role in these pathological alterations. Some studies suggest that medial degeneration is a systemic disease, affecting the whole arterial system [75], whereas others underline the focal nature of medial degeneration, which means that highly affected areas and less affected areas can be found within the same arterial segment [118].

The research in the molecular pathogenesis of $\mathrm{AD}$ is rapidly evolving. The identification of several disease causing mutations by genetic linkage analysis and DNA sequencing showed that ECM structure, TGF-beta signaling and SMC contraction are involved in the pathogenesis of AD. Since SMC contraction requires a functional connective tissue structure and since TGF-beta signaling is important for SMC proliferation, all affected biological systems are related to SMC functioning. Several additional genetic loci for familial AD and aneurysms are currently being studied and it is expected that additional diseasecausing genes will be discovered soon.
First results of genome wide association studies (GWAS) convincingly showed that the CDKN2A/ CDKN2B locus on chromosome 9p21.3 is involved in the pathogenesis of $\mathrm{AD}$ and other arterial diseases. Large study samples are required for GWAS with high power. This research method is suitable for the study of aortic dissections and first results of a large GWAS of cervical AD are to be expected in the near future [143]. Due to their low incidence, it will be difficult to analyze renal or coronary AD by the GWAS technology.

Acknowledgments The authors are indebted to Marie-Luise Arnold and Stefan Engelter for valuable comments.

\section{References}

1. Tsai TT, Trimarchi S, Nienaber CA (2009) Acute aortic dissection: perspectives from the International Registry of Acute Aortic Dissection (IRAD). Eur J Vasc Endovasc Surg 37:149_ 159

2. Schievink WI (2001) Spontaneous dissection of the carotid and vertebral arteries. N Engl J Med 344:898-906

3. Bickerstaff LK, Pairolero PC, Hollier LH, Melton LJ, Van Peenen HJ, Cherry KJ, Joyce JW, Lie JT (1982) Thoracic aortic aneurysms: a population-based study. Surgery 92:1103-1108

4. Lee VH, Brown RD, Mandrekar JN, Mokri B (2006) Incidence and outcome of cervical artery dissection: a population-based study. Neurology 67:1809-1812

5. Trimarchi S, Tsai T, Eagle KA, Isselbacher EM, Froehlich J, Cooper JV, Rampoldi V, Upchurch GR Jr, International Registry of Acute Aortic Dissection (IRAD) investigators (2007) Acute abdominal aortic dissection: insight from the International Registry of Acute Aortic Dissection (IRAD). J Vasc Surg 46:913-919

6. Dittrich R, Nassenstein I, Bachmann R, Maintz D, Nabavi DG, Heindel W, Kuhlenbaumer G, Ringelstein EB (2007) Polyarterial clustered recurrence of cervical artery dissection seems to be the rule. Neurology 69:180-186

7. Debette S, Leys D (2009) Cervical-artery dissections: predisposing factors, diagnosis, and outcome. Lancet Neurol 8:668678

8. Patel PD, Arora RR (2008) Pathophysiology, diagnosis, and management of aortic dissection. Ther Adv Cardiovasc Dis 2:439-468

9. Smith GD, Timpson N, Ebrahim S (2008) Strengthening causal inference in cardiovascular epidemiology through Mendelian randomization. Ann Med 40:524-541

10. Bochud M (2008) On the use of Mendelian randomization to infer causality in observational epidemiology. Eur Heart $\mathrm{J}$ 29:2456-2457

11. Brandt T, Grond-Ginsbach C (2002) Spontaneous cervical artery dissection: from risk factors towards pathogenesis. Stroke 33:657-658

12. Rubinstein SM, Peerdeman SM, van Tulder MW, Riphagen I, Haldeman S (2005) A systematic review of the risk factors for cervical artery dissection. Stroke 36:1575-1580

13. Rothwell DM, Bondy SJ, Williams JI (2001) Chiropractic manipulation and stroke: a population-based case-control study. Stroke 32:1054-1060

14. Saeed IM, Braverman AC (2007) Approach to the athlete with thoracic aortic disease. Curr Sports Med Rep 6:101-107 
15. Iqbal FM, Goparaju M, Yemme S, Lewis BE (2009) Renal artery dissection following marathon running. Angiology 60:122-126

16. Choi JW, Davidson CJ (2002) Spontaneous multivessel coronary artery dissection in a long-distance runner successfully treated with oral antiplatelet therapy. J Invasive Cardiol 14:675-678

17. Hatzaras I, Tranquilli M, Coady M, Barrett PM, Bible J, Elefteriades JA (2007) Weight lifting and aortic dissection: more evidence for a connection. Cardiology 107:103-106

18. Houser OW, Mokri B, Sundt TM, Baker HL, Reese DF (1984) Spontaneous cervical cephalic arterial dissection and its residuum: angiographic spectrum. Am J Neuroradiol 5:27-34

19. Vertinsky AT, Schwartz NE, Fischbein NJ, Rosenberg J, Albers GW, Zaharchuk G (2008) Comparison of multidetector CT angiography and MR imaging of cervical artery dissection. Am J Neuroradiol 29:1753-1760

20. Evangelista A, Mukherjee D, Mehta RH, O'Gara PT, Fattori R, Cooper JV, Smith DE, Oh JK, Hutchison S, Sechtem U, Isselbacher EM, Nienaber CA, Pape LA, Eagle KA, International Registry of Aortic Dissection (IRAD) Investigators (2005) Acute intramural hematoma of the aorta: a mystery in evolution. Circulation 111:1063-1070

21. Hering D, Piper C, Hohmann C, Schultheiss HP, Horstkotte D (1998) Incidence, etiology, therapy of spontaneous coronary artery dissection. A prospective monocenter study of 3800 consecutive patients. Z Kardiol 87:961-970

22. Metso TM, Metso AJ, Helenius J, Haapaniemi E, Salonen O, Porras M, Hernesniemi J, Kaste M, Tatlisumak T (2007) Prognosis and safety of anticoagulation in intracranial artery dissections in adults. Stroke 38:1837-1842

23. Lasica RM, Perunicic J, Mrdovic I, Tesic BV, Stojanovic R, Milic N, Simic D, Vasiljevic Z (2006) Temporal variations at the onset of spontaneous acute aortic dissection. Int Heart $\mathrm{J}$ 47:585-595

24. Paciaroni M, Georgiadis D, Arnold M, Gandjour J, Keseru B, Fahrni G, Caso V, Baumgartner RW (2006) Seasonal variability in spontaneous cervical artery dissection. J Neurol Neurosurg Psychiatry 77:677-679

25. Benninger DH, Georgiadis D, Kremer C, Studer A, Nedeltchev $\mathrm{K}$, Baumgartner RW (2004) Mechanism of ischemic infarct in spontaneous carotid dissection. Stroke 35:482-485

26. Smith BM, Holcomb GW 3rd, Richie RE, Dean RH (1984) Renal artery dissection. Ann Surg 200:134-146

27. Huang YC, Chen YF, Wang YH, Tu YK, Jeng JS, Liu HM (2009) Cervicocranial arterial dissection: experience of 73 patients in a single center. Surg Neurol Jan 14. (Epub ahead of print). doi:10.1016/j.surneu.2008.10.002

28. Pezzini A, Caso V, Zanferrari C, Del Zotto E, Paciaroni M, Bertolino C, Grassi M, Agnelli G, Padovani A (2006) Arterial hypertension as risk factor for spontaneous cervical artery dissection. A case-control study. J Neurol Neurosurg Psychiatry 77:95-97

29. Sakata N, Takebayashi S, Kojima M, Masawa N, Suzuki K, Takatama M (2000) Pathology of a dissecting intracranial aneurysm. Neuropathology 20:104-108

30. Elefteriades JA (2008) Thoracic aortic aneurysm: reading the enemy's playbook. World J Surg 32:366-374

31. Kalaga RV, Malik A, Thompson PD (2007) Exercise-related spontaneous coronary artery dissection: case report and literature review. Med Sci Sports Exerc 39:1218-1220

32. Haldeman S, Kohlbeck FJ, McGregor M (1999) Risk factors and precipitating neck movements causing vertebrobasilar artery dissection after cervical trauma and spinal manipulation. Spine 24:785-794

33. Jaigobin C, Silver FL (2000) Stroke and pregnancy. Stroke 31:2948-2951
34. Cini R, Iezzi F, Sordini P, Pasceri V (2008) Spontaneous left main coronary artery dissection. Interact Cardiovasc Thorac Surg 7:943-944

35. Arnold M, Camus-Jacqmin M, Stapf C, Ducros A, Viswanathan A, Berthet K, Bousser MG (2008) Postpartum cervicocephalic artery dissection. Stroke 39:2377-2379

36. Nasiell J, Norman M, Lindqvist PG, Malmstedt J, Bottinga R, Blennow M (2009) Aortic dissection in pregnancy: a lifethreatening disease and a diagnosis of worth considering. Acta Obstet Gynecol Scand Aug 25:1-4 (Epub ahead of print). doi: 10.1080/00016340903214965

37. Azam M, Roberts D, Logan W (1995) Spontaneous coronary dissection associated with oral contraceptive use. Int J Cardiol 48:195-198

38. Farooq MU, Bhatt A, Patel M (2009) Neurotoxic and cardiotoxic effects of cocaine and ethanol. J Med Toxicol 5:134-138

39. De Giorgio F, Vetrugno G, Fucci N, Rainio J, Tartaglione T, Di Lazzaro V, Carbone A (2007) Fatal stroke in a young cocaine drug addict: chemical hair analysis and cervical artery examination twenty months after death. Folia Neuropathol 45:149-152

40. Edmondson DA, Towne JB, Foley DW, Abu-Hajir M, Kochar MS (2004) Cocaine-induced renal artery dissection and thrombosis leading to renal infarction. WMJ 103:66-69

41. Bizzarri F, Mondillo S, Guerrini F, Barbati R, Frati G, Davoli G (2003) Spontaneous acute coronary dissection after cocaine abuse in a young woman. Can J Cardiol 19:297-299

42. Steinhauer JR, Caulfield JB (2001) Spontaneous coronary artery dissection associated with cocaine use: a case report and brief review. Cardiovasc Pathol 10:141-145

43. Hsue PY, Salinas C, Bolger AF, Benowitz NL, Waters DD (2002) Acute aortic dissection related to crack cocaine. Circulation 105:1592-1595

44. Nusair M, Abuzetun JY, Khaja A, Dohrmann M (2008) A case of aortic dissection in a cocaine abuser: a case report and review of literature. Cases J 1:369

45. Forster K, Poppert H, Conrad B, Sander D (2006) Elevated inflammatory laboratory parameters in spontaneous cervical artery dissection as compared to traumatic dissection: a retrospective case-control study. J Neurol 253:741-745

46. Genius J, Dong-Si T, Grau AP, Lichy C (2005) Postacute C-reactive protein levels are elevated in cervical artery dissection. Stroke 36:42-44

47. Grau AJ, Brandt T, Buggle F, Orberk E, Mytilineos J, Werle E, Conradt I, Krause M, Winter R, Hacke W (1999) Association of cervical artery dissection with recent infection. Arch Neurol 56:851-856

48. Guillon B, Berthet K, Benslamia L, Bertrand M, Bousser MG, Tzourio C (2003) Infection and the risk of spontaneous cervical artery dissection: a case-control study. Stroke 34:79-81

49. Amlie-Lefond C, Bernard TJ, Sébire G, Friedman NR, Heyer GL, Lerner NB, DeVeber G, Fullerton HJ, International Pediatric Stroke Study Group (2009) Predictors of cerebral arteriopathy in children with arterial ischemic stroke: results of the International Pediatric Stroke Study. Circulation 119:1417-1423

50. Pfefferkorn T, Saam T, Hacker M, Rominger A, Cyran C, Nikolaou K, Dichgans M (2009) Perivascular inflammation in spontaneous cervical artery dissection: preliminary results of a prospective observational PET and MRI study. Cerebrovasc Dis 27(Suppl 6):61

51. Sakalihasan N, Hustinx R, Limet R (2004) Contribution of PET scanning to the evaluation of abdominal aortic aneurysm. Semin Vasc Surg 17:144-153

52. Defawe OD, Hustinx R, Defraigne JO, Limet R, Sakalihasan N (2005) Distribution of F-18 fluorodeoxyglucose (F-18 FDG) in abdominal aortic aneurysm: high accumulation in macrophages 
seen on PET imaging and immunohistology. Clin Nucl Med 30:340-341

53. Truijers M, Kurvers HA, Bredie SJ, Oyen WJ, Blankensteijn JD (2008) In vivo imaging of abdominal aortic aneurysms: increased FDG uptake suggests inflammation in the aneurysm wall. J Endovasc Ther 15:462-467

54. Kuehl H, Eggebrecht H, Boes T, Antoch G, Rosenbaum S, Ladd S, Bockisch A, Barkhausen J, Erbel R (2008) Detection of inflammation in patients with acute aortic syndrome: comparison of FDG-PET/CT imaging and serological markers of inflammation. Heart 94:1472-1477

55. Schlatmann TJ, Becker AE (1977) Histologic changes in the normal aging aorta: implications for dissecting aortic aneurysm. Am J Cardiol 39:13-20

56. Allaire E, Schneider F, Saucy F, Dai J, Cochennec F, Michineau S, Zidi M, Becquemin JP, Kirsch M, Gervais M (2009) New insight in aetiopathogenesis of aortic diseases. Eur J Vasc Endovasc Surg 37:531-537

57. Olin JW, Pierce M (2008) Contemporary management of fibromuscular dysplasia. Curr Opin Cardiol 23:527-536

58. Plouin PF, Perdu J, La Batide-Alanore A, Boutouyrie P, Gimenez-Roqueplo AP, Jeunemaitre X (2007) Fibromuscular dysplasia. Orphanet J Rare Dis 2:28

59. Ihling C, Szombathy T, Nampoothiri K, Haendeler J, Beyersdorf F, Uhl M, Zeiher AM, Schaefer HE (1999) Cystic medial degeneration of the aorta is associated with p53 accumulation, Bax upregulation, apoptotic cell death, and cell proliferation. Heart 82:286-293

60. He R, Guo D-C, Estrera AL, Safi HJ, Huynh TT, Yin Z, Cao SN, Lin J, Kurian T, Buja LM, Geng Y-J, Milewicz DM (2006) Characterization of the inflammatory and apoptotic cells in the aortas of patients with ascending thoracic aortic aneurysms and dissections. J Thorac Cardiovasc Surg 131:671-678

61. Cheung S, Mithani V, Watson RM (2000) Healing of spontaneous coronary dissection in the context of glycoprotein IIB/ IIIA inhibitor therapy: a case report. Catheter Cardiovasc Interv 51:95-100

62. Guo DC, Papke CL, He R, Milewicz DM (2006) Pathogenesis of thoracic and abdominal aortic aneurysms. Ann N Y Acad Sci 1085:339-352

63. Fontaine V, Jacob M-P, Houard X, Rossignol P, Plissonnier D, Angles-Cano E, Michel J-B (2002) Involvement of the mural thrombus as a site of protease release and activation in human aortic aneurysms. Am J Pathol 161:1701-1710

64. Raffetto JD, Khalil RA (2008) Matrix metalloproteinases and their inhibitors in vascular remodelling and vascular disease. Biochem Pharmacol 75:346-359

65. Zhang X, Shen YH, LeMaire SA (2009) Thoracic aortic dissection: are matrix metalloproteinases involved? Vascular 17:147-157

66. Barbour JR, Spinale FG, Ikonomidis JS (2007) Proteinase systems and thoracic aortic aneurysm progression. J Surg Res 139:292-307

67. Manabe T, Imoto K, Uchida K, Doi C, Takanashi Y (2004) Decreased tissue inhibitor of metalloproteinase-2/matrix metalloproteinase ratio in the acute phase of aortic dissection. Surg Today 34:220-225

68. Borges LF, Touat Z, Leclercq A, Zen AA, Jondeau' G, Franc B, Philippe M, Meilhac O, Gutierrez PS, Michel JB (2009) Tissue diffusion and retention of metalloproteinases in ascending aortic aneurysm and dissections. Hum Pathol 40:306-313

69. Müller BT, Modlich O, Prisack HB, Bojar H, Schipke JD, Goecke T, Feindt P, Petzold T, Gams E, Müller W, Hort W, Sandmann W (2002) Gene expression profiles in the acutely dissected human aorta. Eur J Vasc Endovasc Surg 24:356-364

70. Weis-Müller BT, Modlich O, Drobinskaya I, Unay D, Huber R, Bojar H, Schipke JD, Feindt P, Gams E, Müller W, Goecke T,
Sandmann W (2006) Gene expression in acute Stanford type A dissection: a comparative microarray study. J Transl Med 4:29

71. Choke E, Cockerill GW, Laing K, Dawson J, Wilson WR, Loftus IM, Thompson MM (2009) Whole genome-expression profiling reveals a role for immune and inflammatory response in abdominal aortic aneurysm rupture. Eur $\mathrm{J}$ Vasc Endovasc Surg 37:305-310

72. Absi TS, Sundt TM 3rd, Tung WS, Moon M, Lee JK, Damiano RR Jr, Thompson RW (2003) Altered patterns of gene expression distinguishing ascending aortic aneurysms from abdominal aortic aneurysms: complementary DNA expression profiling in the molecular characterization of aortic disease. J Thorac Cardiovasc Surg 126:344-357

73. Tung WS, Lee JK, Thompson RW (2001) Simultaneous analysis of 1176 gene products in normal human aorta and abdominal aortic aneurysms using a membrane-based complementary DNA expression array. J Vasc Surg 34:143-150

74. Shi C, Awad IA, Jafari N, Lin S, Du P, Hage ZA, Shenkar R, Getch CC, Bredel M, Batjer HH, Bendok BR (2009) Genomics of human intracranial aneurysm wall. Stroke 40:1252-1261

75. Völker W, Besselmann M, Dittrich R, Navabi D, Konrad C, Dziewas R, Evers S, Grewe S, Krämer C, Bachmann R, Stögbauer F, Ringelstein EB, Kuhlenbäumer G (2005) Generalized arteriopathy in patients with cervical artery dissection. Neurology 64:1508-1513

76. Yoshida T, Owens GK (2005) Molecular determinants of vascular smooth muscle cell diversity. Circ Res 96:280-291

77. Hao H, Gabbiani G, Bochaton-Piallat ML (2003) Arterial smooth muscle cell heterogeneity: implications for atherosclerosis and restenosis development. Arterioscler Thromb Vasc Biol 23:1510-1520

78. Dietz HC, Cutting GR, Pyeritz RE, Maslen CL, Sakai LY, Corson GM, Puffenberger EG, Hamosh A, Nanthakumar EJ, Curristin SM, Stetten G, Meyers DA, Francomano CA (1991) Marfan syndrome caused by a recurrent de novo missense mutation in the fibrillin gene. Nature 352:337-339

79. Callewaert B, Malfait F, Loeys B, De Paepe A (2008) EhlersDanlos syndromes and Marfan syndrome. Best Pract Res Clin Rheumatol 22:165-189

80. Faivre L, Collod-Beroud G, Loeys BL, Child A, Binquet C, Gautier E, Callewaert B, Arbustini E, Mayer K, Arslan-Kirchner M, Kiotsekoglou A, Comeglio P, Marziliano N, Dietz HC, Halliday D, Beroud C, Bonithon-Kopp C, Claustres M, Muti C, Plauchu H, Robinson PN, Adès LC, Biggin A, Benetts B, Brett M, Holman KJ, De Backer J, Coucke P, Francke U, De Paepe A, Jondeau G, Boileau C (2007) Effect of mutation type and location on clinical outcome in 1, 013 probands with Marfan syndrome or related phenotypes and FBN1 mutations: an international study. Am J Hum Genet 81:454-466

81. Trotter ES, Olsen EGJ (1991) Marfan's Disease and Erdheim's cystic medionecrosis. A study of their pathology. Eur Heart $\mathrm{J}$ 12:83-87

82. Pepin M, Schwarze U, Superti-Furg A, Byers PH (2000) Clinical and genetic features of Ehlers-Danlos syndrome type IV, the vascular type. N Engl J Med 342:673-680

83. Loeys BL, Schwarze U, Holm T, Callewaert BL, Thomas GH, Pannu H, De Backer JF, Oswald GL, Symoens S, Manouvrier S, Roberts AE, Faravelli F, Greco MA, Pyeritz RE, Milewicz DM, Coucke PJ, Cameron DE, Braverman AC, Byers PH, De Paepe AM, Dietz HC (2006) Aneurysm syndromes caused by mutations in the TGF-beta receptor. N Engl J Med 355:788-798

84. Maleszewski JJ, Miller DV, Lu J, Dietz HC, Halushka MK (2009) Histopathologic findings in ascending aortas from individuals with Loeys-Dietz syndrome (LDS). Am J Surg Pathol 33:194-201

85. Bondy CA (2008) Aortic dissection in Turner syndrome. Curr Opin Cardiol 23:519-526 
86. El-Mansoury M, Barrenäs ML, Bryman I, Hanson C, Larsson C, Wilhelmsen L, Landin-Wilhelmsen K (2007) Chromosomal mosaicism mitigates stigmata and cardiovascular risk factors in Turner syndrome. Clin Endocrinol (Oxf) 66:744-751

87. Elsheikh M, Dunger DB, Conway GS, Wass JA (2002) Turner's syndrome in adulthood. Endocr Rev 23:120-140

88. Gravholt CH, Landin-Wilhelmsen K, Stochholm K, Hjerrild BE, Ledet T, Djurhuus CB, Sylvén L, Baandrup U, Kristensen B $\varnothing$, Christiansen JS (2006) Clinical and epidemiological description of aortic dissection in Turner's syndrome. Cardiol Young $16: 430-436$

89. Kuivaniemi H, Shibamura H, Arthur C, Berguer R, Cole CW, Juvonen T, Kline RA, Limet R, Mackean G, Norrgård O, Pals G, Powell JT, Rainio P, Sakalihasan N, van Vlijmen-van Keulen C, Verloes A, Tromp G (2003) Familial abdominal aortic aneurysms: collection of 233 multiplex families. J Vasc Surg 37:340-345

90. Elefteriades JA (2002) Natural history of thoracic aortic aneurysms: indications for surgery, and surgical versus nonsurgical risks. Ann Thorac Surg 74:1877-1880

91. Milewicz DM, Guo DC, Tran-Fadulu V, Lafont AL, Papke CL, Inamoto S, Kwartler CS, Pannu H (2008) Genetic basis of thoracic aortic aneurysms and dissections: focus on smooth muscle cell contractile dysfunction. Annu Rev Genomics Hum Genet 9:283-302

92. Bromberg JEC, Rinkel GJE, Algra A, Greebe P, van Duyn CM, Hasan D, Limburg M, ter Berg HW, Wijdicks EF, van Gijn J (1995) Subarachnoid haemorrhage in first and second degree relatives of patients with subarachnoid haemorrhage. BMJ 311:288-289

93. Martin JJ, Hausser I, Lyrer P, Busse O, Schwarz R, Schneider R, Brandt T, Kloss M, Schwaninger M, Engelter S, Grond-Ginsbach C (2006) Familial cervical artery dissections: clinical, morphologic and genetic studies. Stroke 37:2924-2929

94. Mayer SA, Rubin BS, Starman BJ, Byers PH (1996) Spontaneous multivessel cervical artery dissection in a patient with a substitution of alanine for glycine (G13A) in the alpha 1(I) chain of type I collagen. Neurology 47:552-556

95. Wagner C, Kloss M, Lichy C, Grond-Ginsbach C (2008) A glycine-valine substitution in alpha2 type $\mathrm{V}$ procollagen associated with recurrent cervical artery dissection. J Neurol 255:1421-1422

96. Brandt T, Orberk E, Weber R, Werner I, Busse O, Muller B, Wigger F, Grau A, Grond-Ginsbach C, Hausser I (2001) Pathogenesis of cervical artery dissections: association with connective tissue abnormalities. Neurology 57:24-30

97. Hausser I, Muller U, Engelter S, Lyrer P, Pezzini A, Padovani A, Moormann B, Busse O, Weber R, Brandt T, Grond-Ginsbach C (2004) Different types of connective tissue alterations associated with cervical artery dissections. Acta Neuropathol (Berl) 107:509-514

98. Grond-Ginsbach C, Schnippering H, Hausser I, Weber R, Werner I, Steiner H, Lüttgen N, Busse O, Grau A, Brandt T (2002) Ultrastructural connective tissue aberrations in patients with intracranial aneurysms. Stroke 33:2192-2196

99. Grond-Ginsbach C, Debette S (2009) The association of connective tissue disorders with cervical artery dissections. Curr Mol Med 9:210-214

100. Wiest T, Grond-Ginsbach C, Werner I, Kotelis D, Geisbuesch P, Boeckler D (2009) No evidence for a potential role of mutations in the acta2 gene in the etiology of cervical artery dissections and thoracic aortic aneurysms. Cerebrovasc Dis 27(Suppl 6):119

101. Faivre L, Collod-Beroud G, Callewaert B, Child A, Loeys BL, Binquet C, Gautier E, Arbustini E, Mayer K, Arslan-Kirchner M, Kiotsekoglou A, Comeglio P, Grasso M, Beroud C, Bonithon-Kopp C, Claustres M, Stheneur C, Bouchot O, Wolf JE,
Robinson PN, Adès L, De Backer J, Coucke P, Francke U, De Paepe A, Boileau C, Jondeau G (2009) Pathogenic FBN1 mutations in 146 adults not meeting clinical diagnostic criteria for Marfan syndrome: further delineation of type 1 fibrillinopathies and focus on patients with an isolated major criterion. Am J Med Genet A 149A:854-860

102. Brooke BS, Karnik SK, Li DY (2003) Extracellular matrix in vascular morphogenesis and disease: structure versus signal. Trends Cell Biol 13:51-56

103. de Wit MC, Kros JM, Halley DJ, de Coo IF, Verdijk R, Jacobs BC, Mancini GM (2009) Filamin A mutation, a common cause for periventricular heterotopia, aneurysms and cardiac defects. J Neurol Neurosurg Psychiatry 80:426-428

104. Hart AW, Morgan JE, Schneider J, West K, McKie L, Bhattacharya S, Jackson IJ, Cross SH (2006) Cardiac malformations and midline skeletal defects in mice lacking filamin A. Hum Mol Genet 15:2457-2467

105. Pilop C, Aregger F, Gorman RC, Brunisholz R, Gerrits B, Schaffner T, Gorman JH 3rd, Matyas G, Carrel T, Frey BM (2009) Proteomic analysis in aortic media of patients with marfan syndrome reveals increased activity of calpain 2 in aortic aneurysms. Circulation 120:983-991

106. Delbosc S, Haloui M, Louedec L, Dupuis M, Cubizolles M, Podust VN, Fung ET, Michel JB, Meilhac O (2008) Proteomic analysis permits the identification of new biomarkers of arterial wall remodeling in hypertension. Mol Med 14:383-394

107. Tran-Fadulu V, Pannu H, Kim DH, Vick GW 3rd, Lonsford CM, Lafont AL, Boccalandro C, Smart S, Peterson KL, Hain JZ, Willing MC, Coselli JS, LeMaire SA, Ahn C, Byers PH, Milewicz DM (2009) Analysis of multigenerational families with thoracic aortic aneurysms and dissections due to TGFBR1 or TGFBR2 mutations. J Med Genet 46:607-613

108. Goumans MJ, Liu Z, ten Dijke P (2009) TGF-beta signaling in vascular biology and dysfunction. Cell Res 19:116-127

109. Chaudhry SS, Cain SA, Morgan A, Dallas SL, Shuttleworth CA, Kielty CM (2007) Fibrillin-1 regulates the bioavailability of TGFbeta1. J Cell Biol 176:355-367

110. Pereira L, Lee SY, Gayraud B, Andrikopoulos K, Shapiro SD, Bunton T, Biery NJ, Dietz HC, Sakai LY, Ramirez F (1999) Pathogenetic sequence for aneurysm revealed in mice underexpressing fibrillin-1. Proc Natl Acad Sci USA 96:3819-3823

111. Guo G, Booms P, Halushka M, Dietz HC, Ney A, Stricker S, Hecht J, Mundlos S, Robinson PN (2006) Induction of macrophage chemotaxis by aortic extracts of the mgR Marfan mouse model and a GxxPG-containing fibrillin-1 fragment. Circulation 114:1855-1862

112. Chung AW, Au Yeung K, Sandor GG, Judge DP, Dietz HC, van Breemen C (2007) Loss of elastic fiber integrity and reduction of vascular smooth muscle contraction resulting from the upregulated activities of matrix metalloproteinase- 2 and -9 in the thoracic aortic aneurysm in Marfan syndrome. Circ Res 101:512-522

113. Chung AWY, Yang HHC, Radomski MW, van Breemen C (2008) Long-term doxycycline is more effective than atenololto prevent thoracic aortic aneurysm in Marfan syndrome through the inhibition of matrix metalloproteinase-2 and -9 . Circ Res 102:e73-e85

114. Robinson PN, Arteaga-Solis E, Baldock C, Collod-Béroud G, Booms P, De Paepe A, Dietz HC, Guo G, Handford PA, Judge DP, Kielty CM, Loeys B, Milewicz DM, Ney A, Ramirez F, Reinhardt DP, Tiedemann K, Whiteman P, Godfrey M (2006) The molecular genetics of Marfan syndrome and related disorders. J Med Genet 43:769-787

115. Gavazzi G, Deffert C, Trocme C, Schäppi M, Herrmann FR, Krause KH (2007) NOX1 deficiency protects from aortic dissection in response to angiotensin II. Hypertension 50:189-196 
116. Habashi JP, Judge DP, Holm TM, Cohn RD, Loeys BL, Cooper TK, Myers L, Klein EC, Liu G, Calvi C, Podowski M, Neptune ER, Halushka MK, Bedja D, Gabrielson K, Rifkin DB, Carta L, Ramirez F, Huso DL, Dietz HC (2006) Losartan, an AT1 antagonist, prevents aortic aneurysm in a mouse model of Marfan syndrome. Science 312:117-121

117. Gambarin FI, Favalli V, Serio A, Regazzi M, Pasotti M, Klersy C, Dore R, Mannarino S, Viganò M, Odero A, Amato S, Tavazzi L, Arbustini E (2009) Rationale and design of a trial evaluating the effects of losartan vs. nebivolol vs. the association of both on the progression of aortic root dilation in Marfan syndrome with FBN1 gene mutations. J Cardiovasc Med (Hagerstown) 10:354362

118. Guo DC, Papke CL, Tran-Fadulu V, Regalado ES, Avidan N, Johnson RJ, Kim DH, Pannu H, Willing MC, Sparks E, Pyeritz RE, Singh MN, Dalman RL, Grotta JC, Marian AJ, Boerwinkle EA, Frazier LQ, LeMaire SA, Coselli JS, Estrera AL, Safi HJ, Veeraraghavan S, Muzny DM, Wheeler DA, Willerson JT, Yu RK, Shete SS, Scherer SE, Raman CS, Buja LM, Milewicz DM (2009) Mutations in smooth muscle alpha-actin (ACTA2) cause coronary artery disease, stroke, and Moyamoya disease, along with thoracic aortic disease. Am J Hum Genet 84:617-627

119. Presley C, Guo D, Estrera AL, Safi HJ, Brasier AR, Vick GW, Marian AJ, Raman CS, Buja LM, Milewicz DM (2007) MYH11 mutations result in a distinct vascular pathology driven by insulin-like growth factor 1 and angiotensin II. Hum Mol Genet 16:2453-2462

120. Lesauskaite V, Tanganelli P, Sassi C, Neri E, Diciolla F, Ivanoviene L, Epistolato MC, Lalinga AV, Alessandrini C, Spina D (2001) Smooth muscle cells of the media in the dilatative pathology of ascending thoracic aorta: morphology, immunoreactivity for osteopontin, matrix metalloproteinases, and their inhibitors. Hum Pathol 32:1003-1101

121. Lesauskaite V, Epistolato MC, Castagnini M, Urbonavicius S, Tanganelli P (2006) Expression of matrix metalloproteinases, their tissue inhibitors, and osteopontin in the wall of thoracic and abdominal aortas with dilatative pathology. Hum Pathol 37:1076-1084

122. Chew DKW, Conte MS, Khalil RA (2004) Matrix metalloproteinase-specific inhibition of $\mathrm{Ca}^{2+}$ entry mechanisms of vascular contraction. J Vasc Surg 40:1001-1010

123. Katoh H, Suzuki T, Hiroi Y, Ohtaki E, Suzuki S, Yazaki Y, Nagai R (1995) Diagnosis of aortic dissection by immunoassay for circulating smooth muscle myosin. Lancet 345:191-192

124. Karakaya O, Barutcu I, Esen AM, Dogan S, Saglam M, Karapinar H, Akgun T, Karavelioglu Y, Esen O, Ozdemir N, Turkmen S, Kaymaz C (2006) Relationship between circulating plasma matrix metalloproteinase-9 (gelatinase-B) concentration and aortic root dilatation. Am J Hypertens 19:361-365

125. Ioannidis JP (2005) Why most published research findings are false. PLoS Med 2:124

126. Ioannidis JP, Ntzani EE, Trikalinos TA, Contopoulos-Ioannidis DG (2001) Replication validity of genetic association studies. Nat Genet 29:306-309

127. Helgadottir A, Thorleifsson G, Magnusson KP, Grétarsdottir S, Steinthorsdottir V, Manolescu A, Jones GT, Rinkel GJ, Blankensteijn JD, Ronkainen A, Jääskeläinen JE, Kyo Y, Lenk GM, Sakalihasan N, Kostulas K, Gottsäter A, Flex A, Stefansson H, Hansen T, Andersen G, Weinsheimer S, Borch-Johnsen K, Jorgensen T, Shah SH, Quyyumi AA, Granger CB, Reilly MP, Austin H, Levey AI, Vaccarino V, Palsdottir E, Walters GB, Jonsdottir T, Snorradottir S, Magnusdottir D, Gudmundsson G, Ferrell RE, Sveinbjornsdottir S, Hernesniemi J, Niemelä M, Limet R, Andersen K, Sigurdsson G, Benediktsson R, Verhoeven EL, Teijink JA, Grobbee DE, Rader DJ, Collier DA, Pedersen O, Pola R, Hillert J, Lindblad B, Valdimarsson EM,
Magnadottir HB, Wijmenga C, Tromp G, Baas AF, Ruigrok YM, van Rij AM, Kuivaniemi H, Powell JT, Matthiasson SE, Gulcher JR, Thorgeirsson G, Kong A, Thorsteinsdottir U, Stefansson $K$ (2008) The same sequence variant on 9p21 associates with myocardial infarction, abdominal aortic aneurysm and intracranial aneurysm. Nat Genet 40:217-224

128. Bilguvar K, Yasuno K, Niemelä M, Ruigrok YM, von Und Zu Fraunberg M, van Duijn CM, van den Berg LH, Mane S, Mason CE, Choi M, Gaál E, Bayri Y, Kolb L, Arlier Z, Ravuri S, Ronkainen A, Tajima A, Laakso A, Hata A, Kasuya H, Koivisto T, Rinne J, Ohman J, Breteler MM, Wijmenga C, State MW, Rinkel GJ, Hernesniemi J, Jääskeläinen JE, Palotie A, Inoue I, Lifton RP, Günel M (2008) Susceptibility loci for intracranial aneurysm in European and Japanese populations. Nat Genet 40:1472-1477

129. Björck HM, Länne T, Alehagen U, Persson K, Rundkvist L, Hamsten A, Dahlström U, Eriksson P (2009) Association of genetic variation on chromosome $9 \mathrm{p} 21.3$ and arterial stiffness. J Intern Med 265:373-381

130. Schunkert H, Götz A, Braund P, McGinnis R, Tregouet DA, Mangino M, Linsel-Nitschke P, Cambien F, Hengstenberg C, Stark K, Blankenberg S, Tiret L, Ducimetiere P, Keniry A, Ghori MJ, Schreiber S, El Mokhtari NE, Hall AS, Dixon RJ, Goodall AH, Liptau H, Pollard H, Schwarz DF, Hothorn LA, Wichmann HE, König IR, Fischer M, Meisinger C, Ouwehand W, Deloukas P, Thompson JR, Erdmann J, Ziegler A, Samani NJ, Cardiogenics Consortium (2008) Repeated replication and a prospective meta-analysis of the association between chromosome 9p21.3 and coronary artery disease. Circulation 117:16751684

131. Consortium MyocardialInfarctionGenetics, Kathiresan S, Voight BF, Purcell S, Musunuru K, Ardissino D, Mannucci PM, Anand S, Engert JC, Samani NJ, Schunkert H, Erdmann J, Reilly MP, Rader DJ, Morgan T, Spertus JA, Stoll M, Girelli D, McKeown PP, Patterson CC, Siscovick DS, O'Donnell CJ, Elosua R, Peltonen L, Salomaa V, Schwartz SM, Melander O, Altshuler D, Ardissino D, Merlini PA, Berzuini C, Bernardinelli L, Peyvandi F, Tubaro M, Celli P, Ferrario M, Fetiveau R, Marziliano N, Casari G, Galli M, Ribichini F, Rossi M, Bernardi F, Zonzin P, Piazza A, Mannucci PM, Schwartz SM, Siscovick DS, Yee J, Friedlander Y, Elosua R, Marrugat J, Lucas G, Subirana I, Sala J, Ramos R, Kathiresan S, Meigs JB, Williams G, Nathan DM, MacRae CA, O'Donnell CJ, Salomaa V, Havulinna AS, Peltonen L, Melander O, Berglund G, Voight BF, Kathiresan S, Hirschhorn JN, Asselta R, Duga S, Spreafico M, Musunuru K, Daly MJ, Purcell S, Voight BF, Purcell S, Nemesh J, Korn JM, McCarroll SA, Schwartz SM, Yee J, Kathiresan S, Lucas G, Subirana I, Elosua R, Surti A, Guiducci C, Gianniny L, Mirel D, Parkin M, Burtt N, Gabriel SB, Samani NJ, Thompson JR, Braund PS, Wright BJ, Balmforth AJ, Ball SG, Hall AS, Wellcome Trust Case Control Consortium, Schunkert H, Erdmann J, Linsel-Nitschke P, Lieb W, Ziegler A, König I, Hengstenberg C, Fischer M, Stark K, Grosshennig A, Preuss M, Wichmann HE, Schreiber S, Schunkert H, Samani NJ, Erdmann J, Ouwehand W, Hengstenberg C, Deloukas P, Scholz M, Cambien F, Reilly MP, Li M, Chen Z, Wilensky R, Matthai W, Qasim A, Hakonarson HH, Devaney J, Burnett MS, Pichard AD, Kent KM, Satler L, Lindsay JM, Waksman R, Epstein SE, Rader DJ, Scheffold T, Berger K, Stoll M, Huge A, Girelli D, Martinelli N, Olivieri O, Corrocher R, Morgan T, Spertus JA, McKeown P, Patterson CC, Schunkert H, Erdmann E, LinselNitschke P, Lieb W, Ziegler A, König IR, Hengstenberg C, Fischer M, Stark K, Grosshennig A, Preuss M, Wichmann HE, Schreiber S, Hólm H, Thorleifsson G, Thorsteinsdottir U, Stefansson K, Engert JC, Do R, Xie C, Anand S, Kathiresan S, Ardissino D, Mannucci PM, Siscovick D, O’Donnell CJ, Samani 
NJ, Melander O, Elosua R, Peltonen L, Salomaa V, Schwartz SM, Altshuler D (2009) Genome-wide association of early-onset myocardial infarction with single nucleotide polymorphisms and copy number variants. Nat Genet 41:334-341

132. Gizard F, Amant C, Barbier O, Bellosta S, Robillard R, Percevault F, Sevestre H, Krimpenfort P, Corsini A, Rochette J, Glineur C, Fruchart JC, Torpier G, Staels B (2005) PPAR alpha inhibits vascular smooth muscle cell proliferation underlying intimal hyperplasia by inducing the tumor suppressor p16INK4a. J Clin Invest 115:3228-3238

133. Westhoff JH, Hilgers KF, Steinbach MP, Hartner A, Klanke B, Amann K, Melk A (2008) Hypertension induces somatic cellular senescence in rats and humans by induction of cell cycle inhibitor p16INK4a. Hypertension 52:123-129

134. Hannon GJ, Beach D (1994) p15INK4B is a potential effector of TGF-beta-induced cell cycle arrest. Nature 371:257-261

135. Coselli JS, Wilcken DL, Wang XL, LeMaire SA (2006) A single nucleotide polymorphism in the matrix metalloproteinase 9 gene $(-8202 \mathrm{~A} / \mathrm{G})$ is associated with thoracic aortic aneurysms and thoracic aortic dissection. J Thorac Cardiovasc Surg 131:1045-1052

136. Wang Y, Zhang W, Zhang Y, Yang Y, Sun L, Hu S, Chen J, Zhang C, Zheng Y, Zhen Y, Sun K, Fu C, Yang T, Wang J, Sun J, Wu H, Glasgow WC, Hui R (2006) VKORC1 haplotypes are associated with arterial vascular diseases (stroke, coronary heart disease, and aortic dissection). Circulation 113:1615-1621

137. Worrall BB, Foroud T, Brown RD Jr, Connolly ES, Hornung RW, Huston J 3rd, Kleindorfer D, Koller DL, Lai D, Moomaw CJ, Sauerbeck L, Woo D, Broderick JP, Familial Intracranial Aneurysm Study Investigators (2009) Genome screen to detect linkage to common susceptibility genes for intracranial and aortic aneurysms. Stroke 40:71-76

138. Thompson AR, Golledge J, Cooper JA, Hafez H, Norman PE, Humphries SE (2009) Sequence variant on 9p21 is associated with the presence of abdominal aortic aneurysm disease but does not have an impact on aneurysmal expansion. Eur J Hum Genet 17:391-394

139. Giusti B, Saracini C, Bolli P, Magi A, Sestini I, Sticchi E, Pratesi G, Pulli R, Pratesi C, Abbate R (2008) Genetic analysis of 56 polymorphisms in 17 genes involved in methionine metabolism in patients with abdominal aortic aneurysm. J Med Genet 45:721-730

140. McColgan P, Sharma P (2008) The genetics of carotid dissection: meta-analysis of a MTHFR/C677T common molecular variant. Cerebrovasc Dis 25:561-565

141. Grond-Ginsbach C, Debette S, Pezzini A (2005) Genetic approaches in the study of risk factors for cervical artery dissection. Front Neurol Neurosci 20:30-43

142. Debette S, Markus H (2009) The genetics of cervical artery dissection: a systematic review. Stroke 40:e459-e466

143. Debette S, Metso TM, Pezzini A, Engelter S, Leys D, Lyrer P, Metso AJ, Brandt T, Kloss M, Lichy C, Hausser I, Touzé E,
Markus HS, Abboud S, Caso V, Bersano A, Grau AJ, Altintas A, Amouyel P, Tatlisumak T, Dallongeville J, Grond-Ginsbach C (2009) CADISP-genetics: an International project searching for genetic risk factors of cervical artery dissections. Int J Stroke 4:224-230

144. Censori B, Agostinis C, Partziguian T, Guagliumi G, Bonaldi G, Poloni M (2004) Spontaneous dissection of carotid and coronary arteries. Neurology 63:1122-1123

145. Ritzenthaler T, Derex L, Cakmak S, Garrier O, Doumbé J, Nighoghossian N, Trouillas P (2008) Spontaneous dissections of the carotid arteries in a patient with recent coronary artery dissection. Eur Neurol 59:324-326

146. Marshman LA, Ball L, Jadun CK (2007) Spontaneous bilateral carotid and vertebral artery dissections associated with multiple disparate intracranial aneurysms, subarachnoid hemorrhage and spontaneous resolution. Case report and literature review. Clin Neurol Neurosurg 109:816-820

147. Wakino S, Tawarahara K, Tsuchiya N, Kurosawa Y, Sugihara T, Ando K (2005) Spontaneous multiple arterial dissections presenting with renal infarction and subarachnoid hemorrhage in a patient under treatment for infertility. Circ J 69:368-372

148. Engelter ST, Brandt T, Debette S, Caso V, Lichy C, Pezzini A, Abboud S, Bersano A, Dittrich R, Grond-Ginsbach C, Hausser I, Kloss M, Grau A, Tatlisumak T, Leys D, Lyrer PA (2007) Antiplatelets versus anticoagulation in cervical artery dissection: pathophysiological considerations, observational data, systematic review findings and conclusions by analogy. Stroke 38:2605-2611

149. Nadig S, Barnwell S, Wax MK (2009) Pseudoaneurysm of the external carotid artery-review of literature. Head Neck 31:136139

150. Ahmad F, Turner SA, Torrie P, Gibson M (2008) Iatrogenic femoral artery pseudoaneurysms-a review of current methods of diagnosis and treatment. Clin Radiol 63:1310-1316

151. Renard D, Milhaud D (2007) Images in clinical medicine. Dissecting aneurysm of the posterior cerebral artery. N Engl J Med 357:e27

152. Harradine KA, Akhurst RJ (2006) Mutations of TGFbeta signaling molecules in human disease. Ann Med 38:403-414

153. ten Dijke P, Arthur HM (2007) Extracellular control of TGFbeta signalling in vascular development and disease. Nat Rev Mol Cell Biol 8:857-869

154. Seoane J, Pouponnot C, Staller P, Schader M, Eilers M, Massagué J (2001) TGFbeta influences Myc, Miz-1 and Smad to control the CDK inhibitor p15INK4b. Nat Cell Biol 3:400-408

155. Liu P, Zhang C, Feng JB, Zhao YX, Wang XP, Yang JM, Zhang MX, Wang XL, Zhang Y (2008) Cross talk among Smad, MAPK, and integrin signaling pathways enhances adventitial fibroblast functions activated by transforming growth factorbeta 1 and inhibited by Gax. Arterioscler Thromb Vasc Biol 28:725-731 